UNIVERSIDAD DE LIMA

Escuela de posgrado

Maestria en Derecho Empresarial

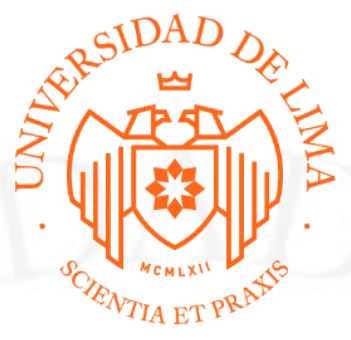

\title{
EL TERCERO DE BUENA FE EN EL REGISTRO DE PREDIOS, A PROPÓSITO DE LA LEY N 30313
}

Trabajo de investigación para optar el grado académico de

Maestro en Derecho Empresarial

\section{HENRY EPHER ANGELES ESPINOZA}

Código 19980847

\section{Asesores}

Jorge Miranda Benavides

Eduardo F. Leturia López

Lima - Perú

Julio de 2019 


\section{THE THIRD OF GOOD FAITH IN THE RECORD OF PREDIES, ON THE PURPOSE OF LAW No. 30313}




\section{TABLA DE CONTENIDO}

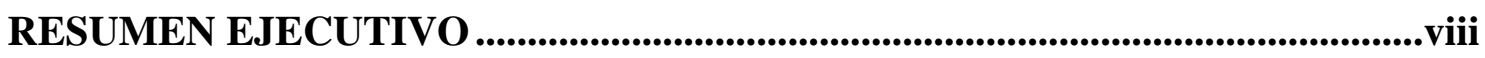

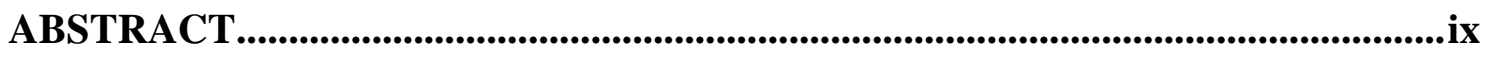

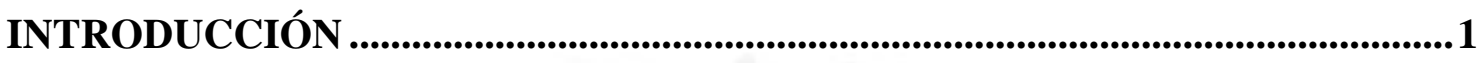

CAPÍTULO I: EL SISTEMA REGISTRAL PERUANO ..........................................2

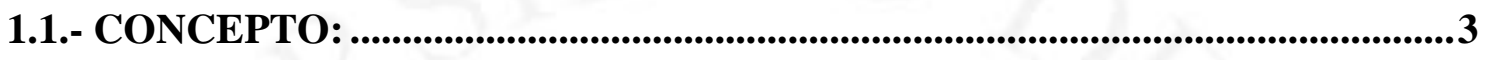

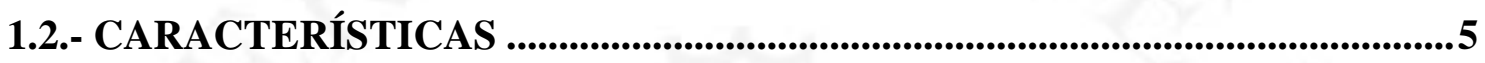

CAPÍTULO II.- LOS PRINCIPIOS REGISTRALES.............................................8

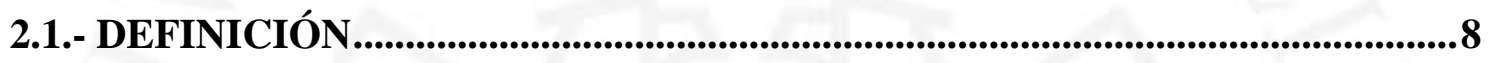

2.2.- PRINCIPIO DE LA BUENA FE PÚBLICA REGISTRAL .................................9

2.2.1.- FUNDAMENTO DE LA FE PÚBLICA REGISTRAL ............................... 9

2.3 PRINCIPIO DE LEGITIMACIÓN ................................................................................... 11

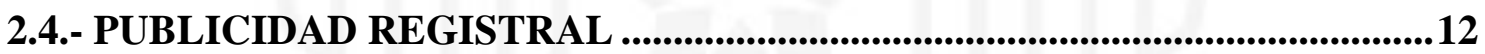

CAPÍtULO III.- GARANTÍAS DEL SISTEMA NACIONAL DE LOS

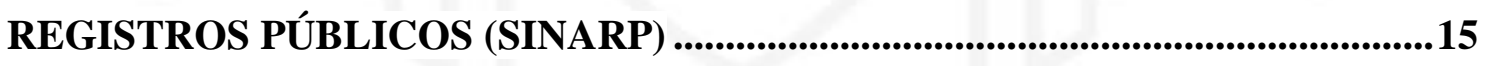

3.1.- AUTONOMÍA DE LOS FUNCIONARIOS E INTANGIBILIDAD DEL CONTENIDO DE LOS ASIENTOS REGISTRALES........................................15

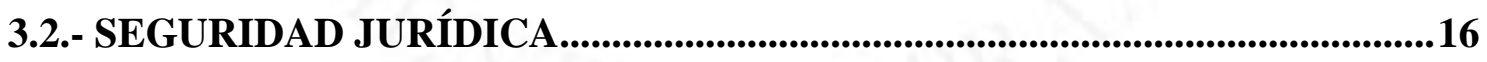

CAPÍtUlo IV.- MECANISMOS PARA PREVENIR O CANCELAR LOS

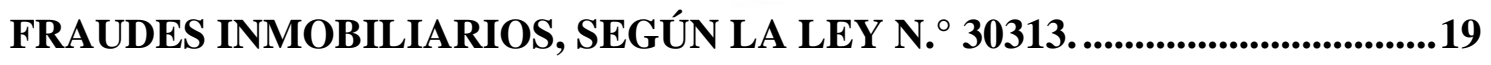

4.1.- OPOSICIÓN AL PROCEDIMIENTO REGISTRAL Y CANCELACIÓN DE INSCRIPCIÓN................................................................................................................... 19

4.1.1- EFECTOS DE LA CANCELACIÓN DE INSCRIPCIÓN.............................2 21

4.2.- MECANISMOS QUE COADYUVAN A LA IDENTIFICACIÓN ...................24

CAPÍTULO V: DERECHO COMPARADO ..................................................................2 27 
5.1.- LEGISLACIONES DE MÉXICO, COSTA RICA Y NICARAGUA...............27

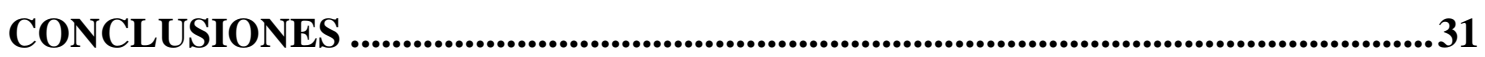

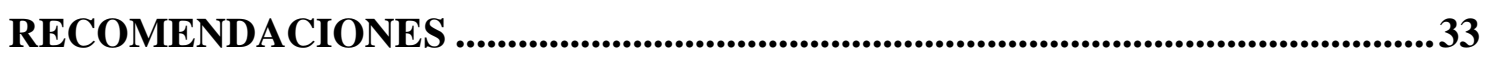

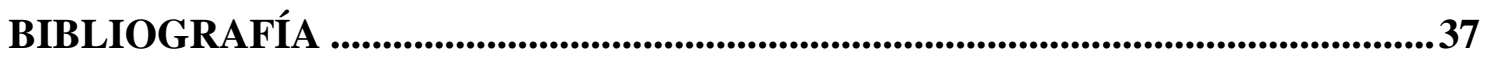

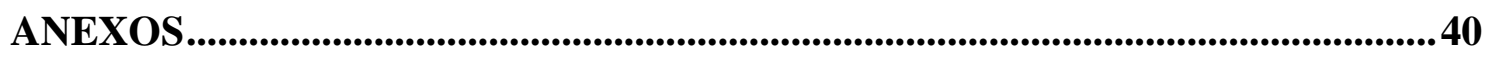




\section{ÍNDICE DE FIGURAS}

Figura 4.1: Tercero adquirente de buena fe ...............................................................21

Figura 4.2: No existe tercero adquirente de buena fe .........................................22 


\section{ÍNDICE DE ANEXOS}

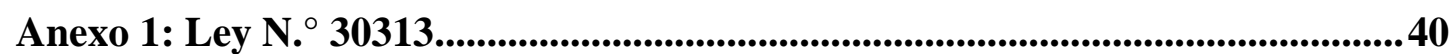

Anexo 2: DECRETO SUPREMO N. ${ }^{\circ}$ 010-2016-JUS.........................................48

Anexo 3: Resolución del Superintendente Nacional de los Registros Públicos

N. ${ }^{0}$ 265-2016-SUNARP-SN ........................................................................................ 74 


\section{RESUMEN}

El propósito de este trabajo es determinar si fue conveniente o no dar nuevas obligaciones a los usuarios de tener que realizar un estudio de títulos que ya habían sido materia de calificación, a fin de que se amparen en la buena fe pública registral, tal como lo exige la Ley N. ${ }^{\circ}$ 30313. Esta ley fue la respuesta del Estado para prevenir y anular el fraude inmobiliario que se venía dando en el país por parte de una organización delictiva que usufructuaba indebidamente del sistema registral y notarial. Esta breve investigación se divide en cinco capítulos; los primeros referidos al sistema registral peruano, los principios registrales, las garantías del sistema nacional de los registros públicos. En el cuarto capítulo se analizan los mecanismos para prevenir o invalidar los fraudes inmobiliarios, se proponen otras alternativas de solución como el uso de la tecnología, a fin reducir los casos de suplantación y falsificación. Finalmente, se analizan a grandes rasgos el derecho comparado en tres países, examinando cómo han regulado la buena fe pública registral.

Palabras clave: Buena fe pública registral, Ley N. 30313, suplantación, falsificación 


\begin{abstract}
The purpose of this work is to determine if it was convenient or not to give new obligations to users who have to do a study of titles that had already been matter of qualification, so that they are protected in good public registry faith, as it is required by the Law No. 30313. This Law was the response of the State to prevent and fight against real estate fraud that was occurring countrywide due to a criminal organization that benefitted unduly from the registry and notary system. This brief investigation is divided in five chapters; the first ones refer to the Peruvian registry system, the registration principles, the guarantees of the national system of public records. In the fourth chapter the mechanisms to prevent or to invalidate real estate frauds are analyzed; other alternatives of solution are proposed, such as the use of the technology in order to reduce cases of forgery and falsification. Finally, comparative Law in three countries is analyzed in a general way, mentioning how they have regulated good public registry faith.
\end{abstract}

Keywsords: Good public registry faith, Law No. 30313, forgery, falsification 


\section{INTRODUCCIÓN}

Esta investigación está referida al principio de buena fe pública registral, a propósito de la modificación del artículo 2014 del Código Civil Peruano mediante la Ley N. ${ }^{\circ} 30313$, la cual busca prevenir y anular el fraude inmobiliario por suplantación de identidad o falsificación de documentos, dado que ahora se tendrá que hacer un estudio de títulos archivados, a pesar de que los mismos ya han sido calificados por un registrador, a fin de poder ampararse en la buena fe pública registral, todo ello debido al fraude inmobiliario realizado por una organización delictiva.

En el Perú, tanto en la doctrina y a nivel legislativo, el tercero registral es a quien se le da protección jurídica cuando contratan en función de la publicidad que brinda registros públicos e inscriben el acto o contrato.

Por ello, este trabajo se ha dividido en cinco capítulos. En el primero de ellos se da un concepto y se detallan las características del sistema registral peruano para luego pasar a investigar en el segundo capítulo el principio de buena fe pública registral, el principio de legitimación y el principio de publicidad, dos de los cuales han sido materia de modificación de la Ley N. ${ }^{\circ}$ 30313. En el capítulo tercero apunta a desarrollar algunas garantías del sistema registral, tales como la autonomía de los funcionarios e intangibilidad del contenido de los asientos registrales y la seguridad jurídica. En el capítulo cuarto se analizan los mecanismos para prevenir o cancelar los fraudes inmobiliarios por suplantación y falsificación según la Ley N. ${ }^{\circ} 30313$, siendo novedosa la oposición al procedimiento registral y a la cancelación administrativa del asiento registral. Asimismo, se proponen algunos mecanismos que coadyuven a la identificación de los contratantes, mediante el uso de la tecnología, pudiendo utilizar de forma alternativa o complementaria el reconocimiento facial y la verificación biométrica para los extranjeros, el cual debe ser implementado en la Superintendencia Nacional de Migraciones. Del mismo modo, alternativas de presentación de documentos ante registros públicos, para lo cual deberán modificarse los artículos pertinentes del Decreto Legislativo del Notariado, que coadyuvará a reducir la falsificación y suplantación. Finalmente, en el quinto capítulo se analizan a grandes rasgos cómo han regulado la fe pública registral algunos países tales como México, Costa Rica y Nicaragua. 


\section{CAPÍTULO I: EL SISTEMA REGISTRAL PERUANO}

A fin de poder determinar el sistema registral que tiene vigencia en el Perú, es necesario estudiar el procedimiento de inscripción, cuáles son los documentos que dan mérito a tal inscripción, cuáles son las normas aplicables, y cuáles los principios registrales que rigen el sistema registral. Los registros que forman parte de la SUNARP son registros jurídicos, siendo en la mayoría de los casos declarativos y en su minoría constitutivos.

Con la Ley N. ${ }^{\circ} 26366$ (1994) se crea la Superintendencia Nacional de Registros Públicos - SUNARP-. El artículo 10 de la mencionada base legal prescribe que:

Créase la Superintendencia Nacional de los Registros Públicos como organismo descentralizado autónomo del Sector Justicia y ente rector del Sistema Nacional de Registros Públicos, con personería jurídica de Derecho Público, con patrimonio propio y autonomía funcional, jurídico registral, técnica, económica, financiera y administrativa; está comprendida en el volumen 05 del presupuesto del Sector Público.

En ese sentido, la SUNARP es un organismo descentralizado y autónomo del Ministerio de Justicia, es decir, es parte de la administración pública, al cual se le aplica la Ley $\mathrm{N}^{\circ} 27444$, Ley del Procedimiento Administrativo General.

Conforme lo establece el artículo 2 de la Ley N. 26366 (1994): “El Sistema Nacional de los Registros Públicos vincula en lo jurídico registral a los Registros de todos los Sectores Públicos...”.

En ese sentido, con dicha Ley al crearse el SINARP se vinculan todos los registros de los sectores públicos, los cuales pueden agruparse en el registro de propiedad inmueble, el registro de propiedad vehicular, el registro de personas naturales y el registro de personas jurídicas, que a su vez unifican otros registros que no serán materia de estudio en esta investigación.

El término registros públicos, se entiende como aquello que está al servicio del usuario, quien puede acceder al mismo sin motivar para qué lo necesita. En ese sentido, 
hay algunos servicios a los cuales se accede de forma gratuita, como el índice de propietarios del registro de predios o los datos del registro de propiedad vehicular. Hay servicios a los cuales se accede previo pago de la tasa correspondiente. Por ejemplo, si alguien desea saber si determinada persona tiene facultades de representación y si se encuentran vigentes o no, tendrá que solicitar la vigencia de poder o el certificado literal y además revisar el título archivado.

"Ese es uno de los pilares que justifica la existencia de los registros: la llamada cognoscibilidad general; esto es, la posibilidad de conocer, aunque efectivamente no se haya conocido." (Becerra Sosaya, 2016, pág. 5).

Nos encontramos ante una posibilidad de conocimiento, por el cual nadie puede desconocer lo inscrito, pues se presume iure et de iure, es decir, que todos tienen conocimiento del contenido del registro, siendo suficiente extender la buena fe pública registral solo al asiento registral.

Conforme a lo mencionado en el capítulo, se pretende definir al sistema registral provisto de un cuerpo normativo definido como "conjunto de reglas o principios enlazados entre sí sobre alguna materia: así se dice, sistema de gobierno, sistema de enjuiciamiento, etc”. (Garcia Calderon, 2007, pág. 1727).

"Respecto a los sistemas registrales, generalmente estos responden al nombre del país de origen. Así tenemos el sistema registral alemán, francés, español, argentino, peruano, etc...." (Alca Robles, 2014, pág. 20 y 21).

En efecto, los sistemas registrales guardan concordancia con el nombre del país de origen, salvo algunas excepciones donde llevan el nombre de la persona que los creó, como el sistema Torrens, creado por Roberto Torrens en Australia.

\section{1.- CONCEPTO:}

El sistema registral peruano está conformado por principios regulados en el Código Civil, en el Texto Único Ordenado del Reglamento General de los Registros Públicos y otros reglamentos, que le dan una característica diferente de los demás sistemas registrales del mundo.

Algunos autores consideran que desde la creación de la SUNARP en el año 1994 existe un sistema registral peruano; sin embargo, en mi opinión el Código Civil de 1984 
ya regulaba los principios registrales pues ya se tenía conocimiento de las características y beneficios del sistema registral peruano. Considero que el sistema registral peruano tiene existencia antes del año 1994.

A partir de la creación del sistema Nacional de los Registros Públicos y de la Superintendencia Nacional de los Registros Públicos, el 14 de octubre de 1994, por ley 26366, sí existe un Sistema Registral Peruano, porque tiene normas legales, reglas y principios propios; y una determinada organización que la caracteriza, singulariza y distingue. (Salgado Padilla, 2011, pág. 63)

Conforme menciona (Moisset de Espanés, 2015, pág. 58):

La publicidad puede conseguir por distintos medios que hagan posible a los terceros conocer determinadas situaciones jurídicas.

Quizás el primer "medio" de dar publicidad a un derecho es su exteriorización posesoria, y el cambio de titularidades que se traduce en la entrega de la cosa; pero, como veremos luego la posesión resulta insuficiente como medio de publicidad.

El ingenio del hombre procura entonces encontrar técnicas que le brinden otros medio para lograr ese objetivo, como las que hemos mencionado más arriba del "anuncio", por medio de pregones, o de proclamas que se colocaban en las paredes de la Iglesia o de edificios públicos.

Pero esas formas de publicidad tenían el defecto de no perdurar en el tiempo, por lo cual se ideó como técnica el asentar los datos que deseaban darse publicidad en un libro de registro, que permitiese a todos los interesados consultarlos en cualquier momento.

Se puede desprender que uno de los fines de la inscripción es la publicidad, y se realizó a través de la inscripción en el registro a fin de hacerlo oponible a terceros. 
El sistema registral peruano está conformado por principios registrales propios, similares a la de otros sistemas, los cuales le otorgan determinados efectos jurídicos hacia los terceros.

El primero de estos intereses, la seguridad estática, suele encontrar defensa suficiente en la exteriorización posesoria del derecho, y la prohibición general de turbar la tranquilidad y la paz públicas. Pero la exteriorización posesoria resulta insuficiente para proteger la seguridad dinámica, y entonces suele aparecer la publicidad registral como medio idóneo para contribuir a la seguridad del tráfico, poniendo al alcance de cualquier interesado la posibilidad de tomar conocimiento de la situación jurídica del bien, su libre disponibilidad o los gravámenes y cargas que sobre él pesan. (Moisset de Espanés, 2015, pág. 50 y 51)

Lo que busca el sistema registral es publicitar determinados actos y/o contratos, a fin de favorecer la seguridad del tráfico. Es necesario mencionar que algunos actos y/o contratos que acceden al registro son declarativos en su mayoría y otros constitutivos en su minoría como la unión de hecho, la constitución de patrimonio familiar y la hipoteca.

El artículo 1099 del Código Civil del Perú (1984), prescribe que:

Son requisitos para la validez de la hipoteca:

1.- Que afecte el bien el propietario o quien esté autorizado para ese efecto conforme a ley.

2.- Que asegure el cumplimiento de una obligación determinada o determinable.

3.- Que el gravamen sea de cantidad determinada o determinable y se inscriba en el registro de la propiedad inmueble.

Se advierte en el inciso 3 del artículo mencionado que se considera como un requisito de validez que la hipoteca se inscriba en el registro de predios, de modo que es constitutiva la inscripción, sin embargo, son pocos los actos jurídicos que tienen naturaleza constitutiva en el Perú.

\section{2.- CARACTERÍSTICAS}


Mencionaré a mi entender algunas características del sistema registral peruano:

No es convalidante, esto es, por el hecho de que se inscriba el título no quiere decir que esté saneado, dado que sigue adoleciendo de defectos.

Es oponible a terceros, es decir, la inscripción se opone a lo no inscrito; el contenido de las inscripciones se presume que es conocido por todos sin admitirse prueba en contrario.

Tenemos el principio de legitimación de lo inscrito, donde se presume que los asientos registrales son válidos y exactos.

Su relevancia se concentra en el ámbito judicial, administrativo y contractual, pero, tratándose de una presunción, no constituye en norma protectora, sino en simple regla simplificadora de la prueba en el tráfico. Precisamente, por su carácter de presunción, cabe la prueba en contrario. (Gonzales Barrón G. H., 2016, pág. 58)

Los asientos registrales se presumen ciertos y válidos, en virtud al principio de legitimación que permite a los terceros tener la certeza de que lo que está publicitado tiene la característica de válida y exacta, facilitando las transacciones. Sin embargo, ello constituye una presunción, dado que tales asientos pueden ser rectificados por las instancias registrales o incluso es factible que el poder judicial o, en la vía arbitral, mediante resolución o laudo firme, se declare la invalidez del asiento registral.

El sistema goza del principio de buena fe pública registral, que se encuentra regulado en el art. 2014 del Código Civil y ha sido materia de modificación en el año 2015, mediante la Ley $\mathrm{N}{ }^{\circ} 30313$, la cual posee requisitos para poder acogerse al artículo mencionado, y que será materia de análisis más adelante.

Cuenta con un sistema causal, donde las inscripciones se realizan en virtud a la calificación de determinado acto jurídico causa de la inscripción.

Nuestro sistema registral es declarativo, dado que el derecho se consolida o se constituye fuera del registro y también existen actos constitutivos, los cuales nacen con la inscripción. En ambos casos le son aplicables los principios registrales mencionados líneas arriba. 
En el registro de predios la inscripción es generalmente declarativa; esto quiere decir que el acto nace fuera del registro, razón por la cual no necesita de la inscripción para su existencia.

"Declarativo o potestativo, reconoce la preexistencia, - extraregistral,- de los derechos, de los que toma razón para su publicidad y otros efectos regulados por ley." (Soria Alarcon M. F., 1997, pág. 20).

En ese sentido, el acto o derecho que accede al registro goza de los beneficios que otorga el sistema registral peruano, esto es, la publicidad, la buena fe registral; entre otros.

La propiedad, por naturaleza, es absoluta (art. $923 \mathrm{CC}$ ), y si el mecanismo de transmisión opera con el solo contrato transmisivo (art. 949 CC), entonces el adquirente se convierte en titular dominial para todos los efectos en virtud de la citada norma legal. (Gonzales Barrón G. H., 2010, pág. 63)

En el Perú, la transmisión de propiedad es consensual, es decir, la transferencia de propiedad se realiza sin necesidad de inscripción en el registro, por ser declarativo. 


\section{CAPÍTULO II.- LOS PRINCIPIOS REGISTRALES}

\section{1.- DEFINICIÓN}

Quisiera empezar este numeral citando a diversos autores a fin de determinar cómo definen los principios:

"Los principios registrales son las reglas fundamentales que sirven de base al sistema hipotecario a un país determinado, y que pueden especificarse por inducción o abstracción de los diversos preceptos del derecho positivo", conforme menciona Sanz citado en (Nuñez Palomino y Uchuya Carrasco, 2000, pág. 186).

La Cruz citado por (Nuñez Palomino y Uchuya Carrasco, 2000, pág. 186) entiende por principios registrales: “aquellas reglas más generales de la legislación hipotecaria española, formuladas directamente en ella u obtenidas por inducción de sus preceptos, que dan a conocer las líneas esenciales de nuestro sistema jurídico registral.”

Por ello, puedo entender los principios registrales como aquellas características que le dan una particularidad específica a determinado sistema registral o aquellas normas generales en que se sustenta el sistema registral y en función a ello se legisla.

En el año 2015 se modificaron legislativamente algunos principios registrales como respuesta al fraude inmobiliario realizado por una organización delictiva. Lo cual me motivo a hacer este trabajo, afín de proponer algunas alternativas de solución que eviten el fraude inmobiliario.

En el Perú tenemos regulados los principios registrales en los artículos $2010^{\circ}$ al $2017^{\circ}$ del Código Civil de 1984, tales como el principio de titulación auténtica, el de rogación, de legalidad, de publicidad, de legitimación, de buena fe registral, de tracto sucesivo, de prioridad y el principio de impenetrabilidad.

A modo de antecedente legislativo se aprecia que el principio de legitimación no se encontraba contemplado en el Código Civil de 1936. Posteriormente, el Código Civil de 1984 lo reguló y la Ley 26366 se estableció como una de las garantías del sistema nacional de los registros públicos (SINARP). 
En esta investigación no se estudian todos los principios del sistema registral peruano pues no es el propósito, sino que se analizan los principios que fueron objeto de modificación en la Ley N. 30313.

\section{2.- PRINCIPIO DE LA BUENA FE PÚBLICA REGISTRAL}

Este principio es uno de los más trascendentales a mi entender, regulado en el artículo 2014 del Código Civil del Perú y modificado el año 2015, mediante la Ley $\mathrm{N}^{\circ} 30313$, en cuyo dictamen se advierten posiciones a favor y en contra de la modificación.

Dicho principio definitivamente implica la consagración de la aseveración aquella que divide al sistema de derecho común, con el sistema registral. $\mathrm{Y}$ es que para fines estrictamente didácticos, aun cuando el sistema jurídico peruano es uno solo, podemos dividirlo o hacer referencia a dos subsistemas jurídicos: uno de derecho común y otro, el registral. Cada uno de ellos ostenta principios jurídicos propios que los caracteriza, en cuyo caso, los efectos jurídico - sustantivos difieren en su solución ante un mismo problema. (Becerra Sosaya, 2016, pág. 34).

\subsection{1.- FUNDAMENTO DE LA FE PÚBLICA REGISTRAL}

Algunos consideran como fundamento la necesidad de:

Privilegiar la llamada seguridad del tráfico en desmedro de la seguridad estática tiene sus detractores, pues argumentan no sin razón, que es altamente injusto preferir a un actor frente al otro, cuando este último no realizó ningún comportamiento que le haga soportar la solución desfavorable que le dispensa el ordenamiento jurídico. Piénsese en el caso aquél que retrata el artículo $2014^{\circ}$ del código civil (incluso en la venta de un predio por quien lo adquirió mediante un ilícito penal), en el cual se prefiere al adquirente del bien a pesar que adquirió de quien no es el verdadero propietario. (Becerra Sosaya, 2016, pág. 17):

El sistema registral peruano favorece la seguridad del tráfico, en aplicación del principio de buena fe registral, el cual ha sido materia de modificación en el año 2015 , 
estableciendo nuevas obligaciones tales como la verificación del título archivado, sometido a calificación por un Registrador Público y en ocasiones el tribunal registral también lo ha calificado vía apelación.

El artículo 2014 del Código Civil (1984), modificado por la Ley N. 30313 (2015), prescribe que:

El tercero que de buena fe adquiere a título oneroso algún derecho de persona que en el registro aparece con facultades para otorgarlo, mantiene su adquisición una vez inscrito su derecho, aunque después se anule, rescinda, cancele o resuelva el del otorgante por virtud de causas que no consten en los asientos registrales y los títulos archivados que lo sustentan.

La buena fe del tercero se presume mientras no se pruebe que conocía la inexactitud del registro.

En ese sentido, considero que no fue conveniente extenderlo al título archivado, por lo que en mi modesta opinión el artículo 2014 del Código Civil debió haber quedado como: El tercero que de buena fe adquiere a título oneroso algún derecho de persona que en el registro aparece con facultades para otorgarlo, mantiene su adquisición una vez inscrito su derecho, aunque después se anule, rescinda, cancele o resuelva el del otorgante en virtud a causas que no consten en los asientos registrales.

La buena fe del tercero se presume mientras no se pruebe que conocía la inexactitud del registro.

Considero que el asiento registral es producto de una calificación exhaustiva a cargo de un profesional especializado. No era entonces necesario imponer nuevas obligaciones al usuario de verificar nuevamente el título archivado.

Con la modificación de la Ley 30313, se debe realizar un estudio del título que dio mérito a la inscripción para poder ampararse en la buena fe pública registral, lo cual no era necesario por ser el asiento registral intangible de acuerdo con la Ley N. 26366 , ley que constituye una de las garantías del sistema nacional de los registros públicos.

Además, la suplantación de identidad o falsificación de documentos no es evidente en los títulos que dan mérito a la inscripción, por lo que la verificación del título archivado no ayuda a reducir el fraude inmobiliario. 
De igual modo, la labor calificadora comprende la verificación de la legalidad de los documentos en virtud a los cuales se solicita la inscripción. Comprende también la capacidad de los otorgantes y la validez del acto, de acuerdo con lo prescrito en el artículo 2014 del Código Civil, por lo que nuestro sistema registral brinda todas las características de seguridad para otorgar certeza del contenido de las inscripciones.

Al extenderlo al título archivado, no se logra favorecer el tráfico inmobiliario, el cual tiene que ser concordante con la Constitución Política del Perú (1993), que prescribe en su artículo 70:

El derecho de propiedad es inviolable. El Estado lo garantiza. Se ejerce en armonía con el bien común y dentro de los límites de ley. A nadie puede privarse de su propiedad sino, exclusivamente, por causa de seguridad nacional o necesidad pública, declarada por ley, y previo pago en efectivo de indemnización justipreciada que incluya compensación por el eventual perjuicio. Hay acción ante el Poder Judicial para contestar el valor de la propiedad que el Estado haya señalado en el procedimiento expropiatorio.

El Estado debe garantizar la propiedad dado que la regla general es que el legítimo propietario disponga de la propiedad, siendo que el legislador debe establecer mecanismos de protección y prevención a fin de evitar los fraudes, sin desmotivar el tráfico inmobiliario.

\subsection{PRINCIPIO DE LEGITIMACIÓN}

El asiento registral es un resumen producto de una exhaustiva calificación realizada por un registrador especializado. Dicho asiento registral goza del principio de legitimación, siendo que se presume cierto y produce todos sus efectos.

El principio de legitimación regulado de forma primigenia en el artículo 2013 del Código Civil, prescribe que: "El contenido de la inscripción se presume cierto y produce todos sus efectos, mientras no se rectifique o se declare judicialmente su invalidez."; sin embargo, el año 2015 ha sido modificado mediante la Ley $N^{\circ} 30313$, cuyo texto es el siguiente:

El contenido del asiento registral se presume cierto y produce todos sus efectos, mientras no se rectifique por las instancias registrales o se declare 
su invalidez por el órgano judicial o arbitral mediante resolución o laudo firme.

El asiento registral debe ser cancelado en sede administrativa cuando se acredite la suplantación de identidad o falsedad documentaria y los supuestos así establecidos con arreglo a las disposiciones vigentes.

La inscripción no convalida los actos que sean nulos o anulables con arreglo a las disposiciones vigentes.

Me encuentro de acuerdo con dicha modificación dado que el Estado peruano debe establecer remedios o soluciones a actos ilícitos y evitar el perjuicio de los legítimos propietarios, de forma que garantice la inviolabilidad de la propiedad.

Con la cancelación administrativa se puede evitar que el bien sea transferido a una tercera persona; en consecuencia, no puede ampararse en la buena fe pública registral. Se evitan perjuicios a los legítimos propietarios, lo cual será desarrollado más adelante.

\section{4.- PUBLICIDAD REGISTRAL}

¿Qué entendemos por publicidad?, veamos esta definición:

Podemos conceptualizar diciendo que la publicidad registral consiste en la exteriorización ininterrumpida de una determinada situación o relación jurídica existente en los registros públicos, al alcance de la cognosibilidad general para la protección del tráfico de los derechos y la seguridad de los mismos. (Salgado Padilla, 2011, pág. 20)

La publicidad que brinda la Sunarp es una publicidad jurídica, la cual debe estar al alcance del usuario de forma permanente e ininterrumpida las 24 horas del día, todo el año. Además, es oportuno precisar que no se necesita expresión de causa para solicitar la publicidad.

Dicha publicidad tiene efectos jurídicos, presumiéndose que todos tienen conocimiento del contenido de las inscripciones, protegiendo el derecho de las personas que tienen su derecho inscrito.

Se suele distinguir tanto a nivel doctrinario como legislativo, dos clases de publicidad, material y formal. 
La publicidad material es aquella que se encuentra en los asientos registrales o inscripciones, de modo que se establece una presunción donde todos conocen el contenido de las inscripciones, lo cual es una presunción que no admite prueba en contrario.

El numeral I del título preliminar del Texto Único Ordenado del Reglamento General de los Registros Públicos, aprobado por Resolución del Superintendente Nacional de los Registros Públicos N 126-2012-SUNARP-SN (2012), define que:

El Registro otorga publicidad jurídica a los diversos actos o derechos inscritos. El concepto de inscripción comprende también a las anotaciones preventivas, salvo que este Reglamento expresamente las diferencie.

El contenido de las partidas registrales afecta a los terceros aun cuando éstos no hubieran tenido conocimiento efectivo del mismo.

En ese sentido, una de las funciones del registro es otorgar publicidad jurídica de los actos o contratos que son inscritos, estableciéndose además que se presumen que todos tienen conocimiento de lo inscrito, así no hayan intervenido en el acto o contrato.

La publicidad formal es aquella mediante la cual los usuarios se informan del contenido de las inscripciones, ya sea a través de la publicidad simple o publicidad certificada. El numeral II del título preliminar del Tuo del Reglamento General de los Registros Públicos, aprobado por Resolución del Superintendente Nacional de los Registros Públicos N. ${ }^{\circ}$ 126-2012-SUNARP-SN (2012), define que:

El Registro es público. La publicidad registral formal garantiza que toda persona acceda al conocimiento efectivo del contenido de las partidas registrales y, en general, obtenga información del archivo Registral.

El personal responsable del Registro no podrá mantener en reserva la información contenida en el archivo registral salvo las prohibiciones expresas establecidas en los Reglamentos del Registro.

Es público debido a que está a disposición de todos los usuarios, quienes sin expresión de causa solicitan información sobre el contenido de las partidas registrales, 
pagando los derechos registrales correspondientes y presentando su documento oficial de identidad.

Los usuarios tienen el derecho de solicitar información referida al contenido de las partidas registrales, y los servidores públicos tienen la obligación de atender dicho requerimiento, salvo que la información afecte el derecho a la intimidad.

El fundamento de esta regla es evitar el riesgo de la doble venta, pues la falta de publicidad haría que un comprador siempre se encuentre en la incertidumbre de ser o no el primero, con la indeseable falta de seguridad jurídica en el tráfico inmobiliario. (Gonzales Barrón G. H., 2016, pág. 57)

Sin un sistema que no brinde publicidad, sería muy oneroso o quedaría en la incertidumbre la búsqueda para determinar quién es el titular que dispone del bien. La publicidad registral lo simplifica. 


\section{CAPÍTULO III.- GARANTÍAS DEL SISTEMA NACIONAL DE LOS REGISTROS PÚBLICOS (SINARP)}

Con la Ley N. ${ }^{\circ} 26366$ (1994), se crearon también las garantías del Sinarp, entre ellas, la intangibilidad del contenido de los asientos registrales, salvo título modificatorio posterior o sentencia judicial firme, el cual en el artículo 3 establece que:

Son garantías del Sistema Nacional de los Registros Públicos:

a) La autonomía de sus funcionarios en el ejercicio de sus funciones registrales;

b) La intangibilidad del contenido de los asientos registrales, salvo título modificatorio posterior o sentencia judicial firme;

c) La seguridad jurídica de los derechos de quienes se amparan en la fe del Registro; y

d) La indemnización por los errores registrales, sin perjuicio de las demás responsabilidades que correspondan conforme a ley.

\section{1.- AUTONOMÍA DE LOS FUNCIONARIOS E INTANGIBILIDAD DEL CONTENIDO DE LOS ASIENTOS REGISTRALES}

En la Sunarp la función calificadora está a cargo de los registradores públicos y los vocales del tribunal registral, quienes actúan sin estar sometidos a presión o influencias de otras personas, como sus jefes inmediatos. Gozan de total independencia en sus decisiones de índole registral. Esto asegura, por ejemplo, una calificación imparcial acorde con el principio de legalidad, lo cual constituye una garantía que brinda la Ley $\mathrm{N}^{\circ} 26366$.

Con respecto a la intangibilidad del contenido de los asientos registrales, se aprecia que está vinculada al principio de legitimación, lo cual permite tener la certeza de la exactitud del contenido del asiento registral pues una vez que ha sido suscrito por el registrador, no muta el contenido en el transcurso del tiempo. En caso se requiera 
rectificar o modificar el asiento registral, el procedimiento se realiza a través de otro asiento de inscripción, el cual forma parte de la partida registral. Esto constituye una garantía del Sistema Nacional de los Registros Públicos, de modo tal que quien contrata en función de la información que brinda registros públicos, lo hace confiando en su veracidad.

Es necesario acotar que el asiento registral está sujeto a rectificación mediante el mismo título, un título posterior, sentencia judicial o laudo firme. Las modificaciones a las que está sujeta el asiento registral ya están descritas en el texto único del reglamento general de los registros públicos, tales como el error material o de concepto, los cuales se realizan en mérito del mismo título que dio mérito a la inscripción que es materia de rectificación o mediante la presentación otro título posterior.

Resultan de gran importancia para los fines de este trabajo las garantías reguladas en la norma citada, dado que es la forma cómo los terceros perciben la protección de su derecho luego de realizar una inscripción o cuando realizan alguna transacción en función de la información que brinda el registro. Los usuarios confían en que se ha realizado una adecuada labor de calificación efectuada por el registrador y en ocasiones el tribunal registral también ha calificado vía apelación. Dicho en otras palabras, es cómo se percibe al Estado al brindar seguridad jurídica mediante los registros públicos.

\section{2.- SEGURIDAD JURÍDICA}

El Registro tiene como base brindar seguridad jurídica, a efectos de que terceros tengan la certeza sobre el acto o derecho inscrito es oponible a los terceros.

A continuación, citaré algunos autores para determinar qué entienden por seguridad jurídica:

La seguridad jurídica debe concebirse como la eficacia propia de los sistemas jurídicos en tanto sistemas normativos; un sistema normativo se caracteriza precisamente por su capacidad para generar predicciones sobre hechos o actos futuros; su misión es orientar la conducta de las personas de manera que dicha orientación pueda servir, a su vez, como esquema de interpretación de un determinado sector de la realidad. (Garcia Manrique, 2012, pág. 337 y 338) 
Se aprecia que la seguridad jurídica está plasmada en dispositivos normativos que regulan las consecuencias de los actos jurídicos, haciéndola predictible.

Cavalcanti Filho, Pintore y Jori citados por (Ávila, 2012, pág. 101) precisa “...la seguridad jurídica es la posibilidad de que el sujeto conozca, antes de actuar, la valoración que el ordenamiento jurídico hará de sus acciones...”.

Se advierte que la seguridad jurídica es cuando el Estado tiene reglas claras en el sistema normativo, de modo tal que cualquier persona tiene conocimiento de sus efectos. Asimismo, implica que todo ciudadano debe respetar dicho sistema.

Soria Alarcon, 2012, pág. 480, señala que: "la seguridad jurídica es, por tanto, dar y recibir, ofrecer confianza y tener confianza..."; en consecuencia, la seguridad jurídica es la forma cómo el Estado brinda certeza y confianza a los ciudadanos, que de antemano ya tienen conocimiento de las reglas vigentes en determinado país.

También se suelen leer en doctrina dos aspectos de la seguridad jurídica, denominados estática y dinámica, donde: "la dimensión estática se refiere al problema del conocimiento del derecho, a su saber, o a la cuestión de la comunicación en el derecho, y revela cuales son las cualidades que debe tener para poder ser considerado 'seguro'”. (Ávila, 2012, pág. 250)

La dimensión dinámica busca "garantizar la respetuosa transición del pasado al presente y del presente al futuro mediante el conocimiento del Derecho." (Ávila, 2012, pág. 253)

Ambas dimensiones están relacionadas entre sí, y para efectos didácticos y de mejor entendimiento se han descrito en dos planos.

En suma, el principio de seguridad jurídica implica procesos de determinación, legitimación, de argumentación y de fundamentación que faciliten la controlabilidad semántico argumentativa de la actuación estatal, por un lado, y la respetabilidad de la actividad del contribuyente fundada en el derecho, por el otro. (Ávila, 2012, pág. 240)

En ese sentido, se requiere de un registro que sea confiable, que esté dotado de todo un sistema de garantías que permita asegurar que lo allí registrado es válido. El Estado debe proveer de un registro que no solo proteja a los que han confiado en el sistema, y 
solicitan la inscripción de algún acto o derecho, sino también a los terceros que han contratado sobre la base de la información que brinda.

El registro busca, por tanto, dotar de publicidad a las situaciones jurídicas referidas a los bienes inmuebles, muebles o diversas situaciones jurídicas; de tal suerte que el titular de la prerrogativa cuente con especiales mecanismos de protección reforzados para la tutela de su derecho. (Gonzales Barrón G. H., 2010, pág. 23) 


\section{CAPÍTULO IV.- MECANISMOS PARA PREVENIR O CANCELAR LOS FRAUDES INMOBILIARIOS, SEGÚN LA LEY N. ${ }^{\circ} 30313$.}

Se aprecia que el Estado a través de diferentes normas ha buscado cautelar y garantizar la seguridad jurídica, antes, durante y después de la inscripción. En ese sentido, antes de la inscripción tenemos el bloqueo registral, la alerta registral, la presentación cautiva y la inmovilización de partida. Durante la calificación del título, tenemos la tacha por falsedad documentaria y la oposición al procedimiento registral, y finalmente, como medidas posteriores a la inscripción de actos fraudulentos, la anotación preventiva notarial por suplantación de identidad o falsificación documentaria y la cancelación de inscripción registral por suplantación o falsificación.

Son materia de análisis en este trabajo, los relacionados con la dación de la Ley N. ${ }^{\circ} 30313$, que a continuación se desarrollan.

\section{1.- OPOSICIÓN AL PROCEDIMIENTO REGISTRAL Y CANCELACIÓN DE INSCRIPCIÓN.}

El artículo primero de la Ley N. $^{\circ} 30313$ establece que el objeto es prevenir y anular las acciones fraudulentas que afecten la seguridad jurídica, la cual es reglamentada mediante el Decreto Supremo N. ${ }^{\circ}$ 010-2016-JUS, estableciendo los requisitos y los aspectos procedimentales para la oposición y cancelación.

El procedimiento registral es de naturaleza no contenciosa, donde no cabe oposición de terceros, salvo que se opongan las personas legitimadas para ello, quienes están reguladas de forma taxativa en el numeral 3.1 del artículo 3 de la Ley 30313 (2015) que prescribe que: "solo se admite el apersonamiento del notario, cónsul, juez, funcionario público o árbitro al procedimiento de inscripción registral en trámite en los casos de suplantación de identidad o falsificación de documentos, mediante la oposición...".

Además, si interviene otra persona diferente de la prevista, en la Ley N. ${ }^{\circ} 30313$, el registrador lo rechazará de plano, lo cual es irrecurrible en la vía administrativa; esto es, que no cabe interponer recurso impugnatorio contra la decisión del registrador. 
En el caso de oposición al procedimiento de inscripción registral, el registrador a cargo del título fraudulento procede a la tacha del título por falsedad documentaria o tacha por suplantación de identidad, previa calificación y verificación.

Si el título que presuntamente adolece de suplantación de identidad o falsificación de documentos ya se encuentra inscrito, se peticiona la cancelación del asiento registral, procedimiento que es competencia del Jefe Zonal de la Oficina Registral. Su decisión es irrecurrible en sede administrativa y en caso de estimarla es ejecutada por el registrador mediante el asiento de cancelación.

Los falsarios patentaron un sistema por el cual se crea un título de propiedad a partir de la "nada", sea por falsificación, suplantación, arbitraje inexistente o prescripción adquisitiva sin citación al dueño, por tanto, el acto A-B es "puro papel", no obstante, en forma inmediata se celebra una sucesiva transferencia, mediante el contrato B-C, para constituir el tercero de buena fe, que busca protección por medio de fe pública registral, prevista en el artículo $2014^{\circ}$ del Código Civil, concordante con el art. $5^{\circ}$ de la Ley $N^{\circ}$ 30313. (Gonzales Barrón G. , 2016, pág. 217)

Las falsificaciones de documentos existen desde muchos años atrás, sin embargo, las realizadas por organizaciones delictivas en los últimos años en el Perú tienen una particularidad, buscan realizar sucesivas transacciones e inscribirlas en los registros públicos, y pretenden ampararse en la fe pública registral, perjudicando al legítimo propietario.

Algunos casos típicos de fraude inmobiliario se realizan con suplantación de identidad o falsificación de documentos, por lo que en la etapa de elaboración de documentos se debe ser riguroso legislativamente para evitar los fraudes inmobiliarios. Y no solo inmobiliarios, sino en todas las transacciones, tales como transferencias de bienes muebles, poderes, etc.

Para ello, es necesario tener conocimiento de la secuencia de elaboración de documentos cuando se realiza alguna transacción, y con ello, se eviten o reduzcan notablemente los actos fraudulentos.

El artículo 949 del Código Civil Peruano prescribe que la transferencia es consensual, pues la sola obligación de enajenar hace al acreedor propietario y en la 
práctica se advierte que se suscribe una minuta que es autorizada por un abogado, quien también es un profesional del derecho que evalúa los documentos y se trataría del primer filtro. Luego se eleva a escritura pública ante un notario, quien es el segundo filtro para evaluar el acto jurídico y finalmente se presenta ante los registros públicos, donde también se evalúa el título, estando ante un tercer filtro. De ello se aprecia que es en el proceso de elaboración o formación del documento y su presentación donde se dan por lo general los casos de suplantación y falsificación.

Imaginemos un predio inscrito a favor de X. Sin embargo, dicho predio es transferido suplantando la identidad del legítimo propietario o falsificando documentos a favor de Y. Este nuevo adquirente transfiere el inmueble a favor de Z. Pues nuestro sistema registral protege a $\mathrm{Z}$, quien vendría a ser el tercero registral, por reunir los requisitos previstos en el Art. 2014 del Código Civil, y quien mantiene su adquisición. Todo ello, a fin de favorecer la seguridad del tráfico.

\subsection{1- EFECTOS DE LA CANCELACIÓN DE INSCRIPCIÓN.}

Analizaremos el efecto de la cancelación de inscripción en el supuesto del título que adolece de suplantación de identidad o falsificación ya se encuentra inscrito y posteriormente se inscribe otra transferencia. Acto seguido se solicita la cancelación del asiento fraudulento, sin embargo, esto no perjudica al tercero adquirente, siempre y cuando cumpla con las condiciones del artículo 2014 del Código Civil. En ese sentido, si bien se cancela el asiento donde consta el acto fraudulento, pero al haberse realizado una transferencia se advierte que el propietario con derecho inscrito afectado no recupera el predio, puesto que el tercer adquirente está protegido por la buena fe pública registral.

Figura 4.1: Tercero adquirente de buena fe
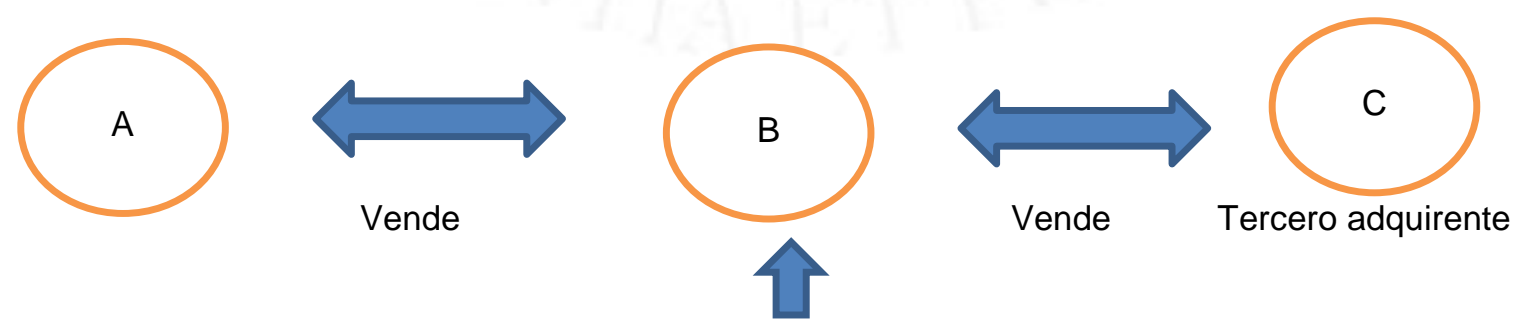

Asiento fraudulento Cancelado

Fuente: Elaboración Propia 
Situación diferente es cuando después de la inscripción del título que adolece de suplantación de identidad o falsificación de documentos y que ha sido cancelado no obra transferencia alguna, donde se advierte que, al no existir tercero registral, el legítimo propietario no se ve perjudicado por el principio de buena fe pública registral.

Además, se aprecia que la cancelación del asiento registral no perjudica a los títulos presentados con anterioridad al asiento de cancelación, de acuerdo con el principio de prioridad.

Figura 4.2: No existe tercero adquirente de buena fe
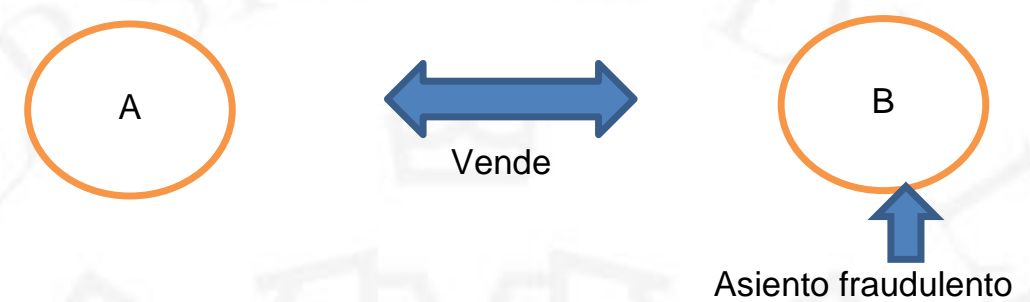

Cancelado

Fuente: Elaboración Propia

Como una alternativa de solución para evitar el fraude inmobiliario, se podría exigir desde la suscripción de la minuta, la verificación biométrica, para poder tener certeza de la identificación de los contratantes. Todo ello, debido a que algunos casos de fraudes inmobiliarios son llevados a cabo a través de procedimientos de prescripción adquisitiva, adjuntado como prueba una minuta fraudulenta. Los colegios de abogados podrían suscribir convenios con el Reniec para facilitar la contratación del servicio y reducir el costo, pues se trataría de una contratación masiva; lo cual contribuiría a garantizar la inviolabilidad de la propiedad y evitar el fraude inmobiliario.

En ese sentido, se advierte que el problema surge fuera de registros públicos, por lo que corresponde realizar las modificaciones normativas que realmente busquen evitarlo en el momento de la transacción.

El objetivo de la norma en general es darle un freno a los supuestos de fraude inmobiliario, utilizando para ello una norma que busca desincentivar esta práctica, a partir de 4 medios: la oposición al trámite, la cancelación del asiento, la modificación del principio de legitimación y fe 
pública en el Código Civil, así como la modificación del Decreto Legislativo del Notariado. (Mendoza Del Maestro, 2015)

En ese sentido, la Ley N ${ }^{\circ} 30313$ regula la oposición al procedimiento registral en trámite y la cancelación del asiento registral por suplantación de identidad o falsificación de documentos. Modifica los artículos 2013 y 2014 del Código Civil y el Decreto Legislativo 1049. Siendo novedosa la posibilidad de presentar una solicitud de oposición al procedimiento, lo cual es realizado por determinadas personas legitimadas.

En adición a ello, con la dación de la Ley N ${ }^{\circ} 30313$ también se otorga la posibilidad a la Sunarp de cancelar un asiento registral por suplantación de identidad o falsificación de documentos, lo cual antes no era factible.

Me encuentro de acuerdo con dicho cambio normativo pues de una $\mathrm{u}$ otra forma se da respuesta inmediata a determinados actos fraudulentos en trámite, o cancelando los inscritos, los cuales solo buscan aprovecharse de los beneficios del sistema registral peruano, perjudicando a los legítimos propietarios.

Finalmente, el legislador modifica con la Ley $\mathrm{N}^{\circ} 30313$; entre otros, el art. 4 del Decreto Legislativo del Notariado N. ${ }^{\circ} 1049$, lo cual no favorece el tráfico inmobiliario y a mi entender no soluciona el fraude inmobiliario. Sin embargo, posteriormente se han modificado las normas referidas a la competencia del notario, las cuales establecen que cualquier notario podría celebrar actos de disposición, - aunque el inmueble se encuentre fuera del ámbito territorial del notario-, si utiliza el sistema de comparación biométrica, de conformidad con la tercera disposición complementaria y modificatoria del Decreto Legislativo $\mathrm{N}^{\circ} 1310$ (2016), que prescribe:

Son nulas de pleno derecho las escrituras públicas de actos de disposición o de constitución de gravamen, realizados por personas naturales sobre predios ubicados fuera del ámbito territorial del notario. Asimismo, la nulidad alcanza a las certificaciones de firmas realizadas por el notario, en virtud de una norma especial en los formularios o documentos privados; sin perjuicio de que de oficio se instaure al notario el proceso disciplinario establecido en el Título IV de la presente ley.

La presente disposición no se aplica al cónsul cuando realiza funciones notariales. 
Asimismo, la restricción no alcanza a los servicios notariales que utilizan el sistema de identificación de comparación biométrica de las huellas dactilares que brinda el Registro Nacional de Identificación y Estado Civil, RENIEC. En caso de extranjeros identificados con carné de extranjería, las transacciones o actuaciones pueden realizarse ante notario de cualquier circunscripción que cuente con acceso a la base de datos de la Superintendencia Nacional de Migraciones.

\section{2.- MECANISMOS QUE COADYUVAN A LA IDENTIFICACIÓN}

En la coyuntura peruana se advierte que los casos típicos de fraude inmobiliario se realizan a través de la falsificación de documentos y suplantación de identidad. En el supuesto de suplantación, mediante el uso de la tecnología se busca implementar mecanismos de seguridad a fin de identificar a las personas. Esto se ha logrado con la verificación biométrica para quienes tienen DNI, de conformidad con el Decreto Legislativo $\mathrm{N} .^{\circ}$ 1049, sin embargo, en caso de extranjeros, ello no resulta factible, por lo que debería implementarse en la Superintendencia Nacional de Migraciones la verificación biométrica de huellas dactilares y/o la identificación facial para reducir los fraudes por suplantación de identidad.

El acceso por parte de los notarios, cónsules, jueces, funcionarios administrativos y árbitros, a la base de datos del RENIEC, respecto de los nacionales, y a la base de datos de la Superintendencia Nacional de Migraciones, en el caso de extranjeros residentes y no residentes, mediante la utilización del sistema de comparación biométrica de las huellas dactilares,... (Tarazona Alvarado, 2017, pág. 325)

Además de ello, también se advierte el fraude inmobiliario a través de la capacidad de los otorgantes, por lo general en los de avanzada edad, quienes cuestionan en el futuro que no se encuentran con la capacidad para poder discernir. En consecuencia, en la vía judicial el acto es declarado nulo por falta de capacidad, por lo que debería exigirse de forma obligatoria a través de la modificación pertinente de la legislación del Notariado el certificado médico de capacidad para mayores de 80 años, para coadyuvar en la evaluación de la capacidad de los contratantes que realiza el notario y evitar en el futuro que el acto sea declarado nulo. 
Con el fin de favorecer el tráfico inmobiliario y evitar suplantaciones, se puede implementar el reconocimiento facial para identificar de forma indubitable a los contratantes, método que puede ser empleado de forma alternativa en caso no sea factible el uso la verificación biométrica, ya sea por problemas en la operatividad del sistema o en la captura de huellas dactilares que no permitan dar la conformidad en la identificación.

Actualmente se presenta de forma remota sólo en algunos registros los partes notariales, por lo que a fin de reducir la presentación de documentos falsificados, se propone que todos los partes notariales o copias certificadas sean presentadas de forma remota al Registro o alternativamente de forma presencial sólo por el notario y/o sus dependientes acreditados en la SUNARP, eliminado la posibilidad que sea presentado por un tercero. En adición a ello, dichos documentos contarían con un código que permita su validación en línea a través de páginas web del colegio de notarios, lo cual contribuirá a tener certeza de la existencia y contenido de los mismos.

Hoy en día es factible validar los partes judiciales o los documentos expedidos por el Reniec a través de sus páginas web, de modo que se tiene certeza de la veracidad del documento, situación que debería replicar no sólo los colegios de notarios, sino también las municipalidades y el archivo general de la nación; entre otros, con el fin de que sólo accedan al registro títulos válidos.

La presentación en línea al Registro de los partes notariales, consulares, judiciales y administrativos, mediante la utilización de la firma digital, dentro de la Infraestructura Oficial de la Firma Electrónica, a fin de garantizar la procedencia legal de dichos documentos (autenticidad, integridad y no repudio) y de esta manera evitar que se presenten documentos falsos. (Tarazona Alvarado, 2017, pág. 325 y 326)

Con la presentación remota del parte notarial de forma obligatoria en todos los registros, se garantiza la intangibilidad de su contenido para que los servidores públicos tengan la certeza de que no ha sido adulterado y es idéntico a la matriz, evitando perjuicios a terceros.

En mi opinión, era necesario dotar al sistema notarial y registral peruano de mayores mecanismos de seguridad mediante el uso de la tecnología y el apoyo del profesional médico, para proteger los derechos de las personas y garantizar e incentivar 
la transferencia de quienes contrataron confiando en la información que brinda los registros públicos. 


\section{CAPÍTULO V: DERECHO COMPARADO}

De forma breve, analizaré diversas normas de otros países relacionadas con el principio de buena fe que es materia de investigación, para determinar cómo garantizan la propiedad al tercero adquirente.

\section{1.- LEGISLACIONES DE MÉXICO, COSTA RICA Y NICARAGUA}

El artículo 3009 del Código Civil de México, prescribe que:

El Registro protege los derechos adquiridos por tercero de buena fe, una vez inscritos, aunque después se anule o resuelva el derecho del otorgante, excepto cuando la causa de la nulidad resulte claramente del mismo registro. Lo dispuesto en este artículo no se aplicará a los contratos gratuitos, ni a actos o contratos que se ejecuten u otorguen violando la Ley. (Código Civil Federal, 1928)

Parte de dicha redacción es similar al artículo 2014 del Código Civil Peruano, sin embargo, queda en incertidumbre si se garantiza o no al tercero de buena fe registral, porque al final de la redacción se menciona que no se aplica a actos o contratos que se ejecuten u otorguen violando la Ley. Puede encontrarse el titulo falsificado del anterior adquirente, favoreciéndose al legítimo propietario, lo cual resulta justo, sin embargo, no se puede confiar en lo inscrito pues está supeditado a que el acto o contrato no contravenga la ley, lo cual debió ser materia de calificación.

Asimismo el artículo 456 del Código Civil de Costa Rica (2016) prescribe que:

La inscripción no convalida los actos o contratos inscritos que sean nulos o anulables conforme a la ley. Sin embargo, los actos o contratos que se ejecuten u otorguen por persona que en el Registro aparezca con derecho para ello, una vez inscritos, no se invalidarán en cuanto a tercero, aunque después se anule o resuelva el derecho del otorgante en virtud de título no 
inscrito, o de causas implícitas, o de causas que aunque explícitas no constan en el Registro.

Se advierte que dicha redacción era similar a la que se regulaba primigeniamente en el Código Civil Peruano, sin embargo, en Costa Rica se consideran tanto los bienes transferidos a título oneroso y gratuito. Dicho sistema es muy protector del tercero adquirente, porque incluso se consideran las causas implícitas que obran en el registro, las cuales debieron ser advertidas por el servidor a cargo de la inscripción del título. En ese sentido, considero que un sistema con dichas cualidades favorece la transferencia de bienes y da confianza al inversionista o adquirente, pues se puede confiar en la información que brinda el registro.

El Código Civil de Nicaragua prescribe en el artículo 3949:

La inscripción no convalida los actos o contratos inscritos que sean nulos o anulables conforme a la Ley. Sin embargo el tercero que de buena fe adquiera a título oneroso algún derecho de persona que en el Registro aparezca con facultades para transmitirlo, será mantenido en su adquisición, una vez que haya inscrito su derecho, aunque después se anule o resuelva el del otorgante por virtud de causas que no consten en el Registro. Tal protección se producirá siempre que concurran las siguientes circunstancias:

1.- Que sea tercero registral. Se entiende por tercero registral al tercer adquirente, es decir al derecho-habiente de un titular registral a título oneroso;

2.- Que actúe de buena fe. Por buena fe se entiende el desconocimiento por el tercer adquirente de las causas resolutorias del derecho de su transmitente no publicadas por el Registro. La buena fe se presume siempre;

3.- Que la transmisión sea a título oneroso, no gozando, en consecuencia, el adquirente a título gratuito de más protección que la que tuviera su causante o transferente; y 
4.- Que haya inscrito su derecho en el Registro. (Código Civil de Nicaragua, 2014)

Se advierte que en Nicaragua se da protección limitada al tercero de buena fe. Se consideran circunstancias, algunas similares a las del Perú, sin embargo, en el artículo siguiente se establecen excepciones a las acciones rescisorias o resolutorias que perjudican al tercero adquirente.

Además el artículo 3950 del Código Civil de Nicaragua prescribe que:

Las acciones rescisorias o resolutorias no perjudicarán a tercero que haya inscrito su derecho. Exceptuase:

1.- Las acciones de rescisión o resolución que deban su origen a causas que, habiendo sido estipuladas expresamente por las partes, consten en el Registro.

2.- Las acciones rescisorias de enajenaciones en fraude de acreedores en los casos siguientes:

1.- Cuando la segunda enajenación ha sido hecha por título lucrativo.

2.- Cuando el tercero haya tenido conocimiento del fraude del deudor;

$\mathrm{y}$

3.- Cuando se esté en cualquiera de los casos comprendidos en el Capítulo n, Título III de este Libro que trata del fraude de los actos jurídicos; y a los que se refiere dicho Capítulo en su artículo final. (Código Civil de Nicaragua, 2014)

Me encuentro en desacuerdo con algunas causales porque sí son estipuladas expresamente, tales como del inciso 1. Debieron ser advertidas por el registrador que calificaba el título y no debió proceder a inscribirlo. Además, por lo general el fraude a los acreedores requiere de un proceso judicial, en el cual se lo demuestre, razón por la cual un sistema con dichas características no favorece el libre tránsito de bienes, y tampoco genera confianza en la entidad pública a cargo de la inscripción.

Finalmente, solo me encuentro de acuerdo con el subnumeral 2 del inciso 2 del artículo submateria, pues en caso el tercero tenga conocimiento del fraude del deudor, evidentemente se están aprovechando de los beneficios de sistema, perjudicando al 
legítimo propietario, aunque dicho supuesto ya está implícito, de lo contrario dejaría de ser tercero de buena fe. 


\section{CONCLUSIONES}

A continuación mencionaré algunas conclusiones:

- La existencia de los registros se justifica en dos pilares llamados cognoscibilidad general, que es la posibilidad de conocer y el conocimiento efectivo. Se realiza accediendo a los archivos del registro a través de la lectura de títulos archivados o a través de certificados literales o compendiosos; entre otros.

- Tenemos un sistema registral peruano que posee principios regulados en el Código Civil, en el TUO del Reglamento General de los Registros Públicos y otras normas específicas que le dan una característica diferente con los demás sistemas registrales.

- Entre las características del sistema registral peruano tenemos que no es convalidante, es oponible a terceros, goza del principio de legitimación de lo inscrito, existe el principio de buena fe pública registral, se trata de sistema causal, y es por lo general declarativo.

- Con la Ley N. ${ }^{\circ} 26366$, se crearon las garantías del Sinarp, tales como la autonomía de sus funcionarios en el ejercicio de sus funciones registrales, la intangibilidad del contenido de los asientos registrales, la seguridad jurídica de los derechos de quienes se amparan en la fe del registro; entre otros.

- En el Perú, el principio de buena fe registral se encuentra regulado en el Código Civil y ha sido materia de modificación en el año 2015, estableciendo nuevas obligaciones al usuario tales como la verificación del título archivado, procedimiento que evita el tráfico inmobiliario.

- De la sucinta comparación del principio de la buena fe registral en diversos países tales como México, Costa Rica y Nicaragua, me encuentro de acuerdo con la regulación de Costa Rica, porque dicho sistema es protector del tercero adquirente, incluso se tienen en consideración las causas implícitas que obran en el registro, y que debieron ser advertidas por el servidor a cargo de la inscripción del título. En ese sentido, un sistema con dichas cualidades favorece la 
transferencia de bienes y da confianza al inversionista o adquirente, porque se puede confiar en la información que brinda el registro. 


\section{RECOMENDACIONES}

A continuación detallaré algunas recomendaciones:

- Dotar al sistema registral y notarial peruano de mayores mecanismos de seguridad para proteger los derechos de las personas que confiaron en los registros públicos y decidieron inscribir sus títulos, y a los terceros que contrataron confiando en la publicidad que brinda los registros públicos, de modo que se favorezca la seguridad del tráfico. Así, me encuentro parcialmente de acuerdo con la Ley N. ${ }^{\circ}$ 30313, sin embargo, discrepo con la obligación que se le impone de poder verificar el título archivado, dado que éste ya ha sido materia de calificación, por lo que sería conveniente un cambio normativo en dicho sentido, dado que los usuarios deben confiar en los asientos registrales, lo cual es producto de una calificación registral exhaustiva y a cargo de un registrador.

- Los casos típicos de fraude inmobiliario se dan en el supuesto de suplantación de identidad. Mediante el uso de la tecnología, se deberían implementar mecanismos de seguridad para identificar a las personas. Esto se ha logrado con la verificación biométrica para quienes tienen DNI, de conformidad con el Decreto Legislativo $\mathrm{N}^{\circ}$ 1049. Sin embargo, en caso de extranjeros, ello no resulta factible, razón por la cual se debería implementar en la Superintendencia Nacional de Migraciones la verificación biométrica en línea para reducir los casos de suplantación de identidad. Además, debería implementarse el reconocimiento facial de forma alternativa, que coadyuvaría en la identificación de los contratantes de forma indubitable.

- El uso del certificado médico de capacidad para mayores de 80 años, en el que el profesional médico evalúa la capacidad de los adultos mayores, coadyuvando en la función notarial. 
- Se recomienda presentar a todos los registros de forma remota los partes notariales, o de forma alternativa establecer mecanismos de validación en línea con los mismos a través de páginas web, a fin de evitar la falsificación total o parcial de los instrumentos públicos, por ejemplo actualmente es factible validar los expedientes judiciales o los documentos expedidos por el Reniec; sin embargo, todavía no se ha implementado mecanismos de validación en línea para los traslados notariales expedidos por el archivo general de la nación o documentos expedidos por la municipalidad.

- Se podría eliminar la posibilidad de que los partes notariales lo presenten terceros legitimados, pues los partes pueden sufrir alteraciones parciales o totales. 
Alca Robles, W. J. (2014). Los registros Públicos: perspectivas desde la Sunarp - Reniec. Lima: Idemsa.

Ávila, H. (2012). Teoría de la seguridad jurídica. Madrid: Marcial pons.

Becerra Sosaya, M. A. (2016). El tercero registral en el derecho societario y su protección jurídica (trabajo de investigación para optar el grado de maestro en Derecho Empresarial) Universidad de Lima. Obtenido de http://repositorio.ulima.edu.pe/handle/123456789/1304

Civil Civil. (25 de julio de 1984). Recuperado del sitio de internet del Sistema Peruano de Información Jurídica. Obtenido de http://spijlibre.minjus.gob.pe/normativa_libre/main.asp

Código Civil de Costa Rica. (30 de noviembre de 2016). Recuperado del sitio de internet de Vlex. Obtenido de https://2019-vlexcom.ezproxy.ulima.edu.pe/\#search/jurisdiction:CR+content_type:9/fe+publica+ registral+LA+FE+P\%C3\%9ABLICA+REGISTRAL++title\%3A(codigo+civil)+ codigo+civil+ley+hipotecaria/WW/vid/428631197

Código Civil de Nicaragua. (08 de octubre de 2014). Recuperado del sitio de internet de Vlex. Obtenido de https://2019-vlexcom.ezproxy.ulima.edu.pe/\#search/content_type:9+jurisdiction:NI/fe+publica+r egistral+LA+FE+P\%C3\%9ABLICA+REGISTRAL++title\%3A(codigo+civil)+c odigo+civil+ley+hipotecaria/WW/vid/705264933

Código Civil Federal. (31 de agosto de 1928). Recuperado del sitio de internet Vlex. Obtenido de https://2019-vlexcom.ezproxy.ulima.edu.pe/\#search/content_type:9+jurisdiction:MX/codigo+civi 1/WW/vid/42578683

Constitución Política del Perú. (30 de diciembre de 1993). Recuperado del sitio de internet del Sistema Peruano de Información Jurídica. Obtenido de http://spijlibre.minjus.gob.pe/normativa_libre/main.asp

Decreto Legislativo $N^{\circ}$ 1049, Decreto Legislativo del Notariado. (26 de junio de 2008). Recuperado del sitio de internet del Sistema Peruano de información jurídica. Obtenido de http://spijlibre.minjus.gob.pe/normativa_libre/main.asp 
Decreto Legislativo $\mathrm{N}^{\circ}$ 1310, Decreto Legislativo que apueba medidas adicionales de simplificación administrativa. (30 de diciembre de 2016). Recuperado del sitio de internet del Sistema Peruano de información jurídica. Obtenido de http://spijlibre.minjus.gob.pe/normativa_libre/main.asp

Garcia Calderon, F. (2007). Diccionario de la Legislación Peruana. Lima: Laser Graf Alvarado.

Garcia Manrique, R. (2012). El valor de la seguridad jurídica. Madrid: Iustel.

Gonzales Barrón, G. (2016). Sistema registral y contratación inmobiliaria: En la ley $n^{\circ}$ 30313. Lima: Ediciones legales.

Gonzales Barrón, G. H. (2010). Tratado de Derecho Registral Inmobiliario (2a ed. ed., Vol. Tomo1). Lima: Ediciones Legales.

Ley $N^{\circ}$ 26366, Creación del Sistema Nacional y de la Superintendencia de los Registros Públicos. (16 de octubre de 1994). Recuperado del sitio de internet del Sistema Peruano de Información Jurídica. Recuperado el 09 de mayo de 2019, de http://spijlibre.minjus.gob.pe/normativa_libre/main.asp

Ley $\mathrm{N}^{\circ}$ 30313. (26 de marzo de 2015). Recuperado del sitio de internet del Sistema peruano de información juridica. Obtenido de http://spijlibre.minjus.gob.pe/normativa_libre/main.asp

Mendoza Del Maestro, G. (12 de julio de 2015). Recuperado del sitio de internet de Catedra judicial un espacio para compartir el camino a la justicia. Obtenido de http://catedrajudicial.blogspot.com/2015/07/la-ley-n-30313-el-registradorcomo.html

Moisset de Espanés, L. (2015). Publicidad registral ( $1^{\circ}$ ed.). Lima: Sunarp.

Nuñez Palomino, G., y Uchuya Carrasco, H. (2000). Derecho registral doctrina de Roca Sartre. Perú: Azul Grana Editores.

Resolución del Superintendente Nacional de los registros públicos $\mathrm{N}^{\circ}$ 126-2012SUNARP-SN . (22 de mayo de 2012). Recuperado del sitio de internet del Sistema Peruano de Información Jurídica. Obtenido de http://spijlibre.minjus.gob.pe/normativa_libre/main.asp

Salgado Padilla, A. F. (2011). Manual de derecho registral. Lima: Cadillo.

Soria Alarcon, M. F. (1997). Estudios de derecho registral. Lima: Palestra. 
Soria Alarcon, M. F. (2012). Registros públicos: Los contratos con publicidad ; un recorrido a los 28 años de vigencia del libro IX del Código civil. Lima: Jurista editores.

Tarazona Alvarado, F. (2017). El sistema registral peruano y los principios que lo rigen. Lima: Gaceta Notarial. 
Alca Robles, W. J. (2014). Los registros Públicos: perspectivas desde la Sunarp - Reniec. Lima: Idemsa.

Ávila, H. (2012). Teoría de la seguridad jurídica. Madrid: Marcial pons.

Becerra Sosaya, M. A. (2016). El tercero registral en el derecho societario y su protección jurídica (trabajo de investigación para optar el grado de maestro en Derecho Empresarial) Universidad de Lima. Obtenido de http://repositorio.ulima.edu.pe/handle/123456789/1304

De Reina Tartiére, G. (2011). Derecho registral inmobiliario: Manual (2a ed. ed.). Buenos Aires: B y F.

Garcia Calderon, F. (2007). Diccionario de la Legislación Peruana. Lima: Laser Graf Alvarado.

Garcia Manrique, R. (2012). El valor de la seguridad jurídica. Madrid: Iustel.

Gonzales Barrón, G. (2014). Los Principios Registrales en el Conflicto Judicial. Lima: Ediciones Legales.

Gonzales Barrón, G. (2016). Sistema registral y contratación inmobiliaria: En la ley $n^{\circ}$ 30313. Lima: Ediciones legales.

Gonzales Barrón, G. H. (2010). Tratado de Derecho Registral Inmobiliario (2a ed. ed., Vol. Tomo1). Lima: Ediciones Legales.

Gonzales Barrón, G. H. (2016). Sistema registral y contratación inmobiliaria: En la ley $n^{\circ}$ 30313. Lima: Ediciones Legales.

Gordillo Cañas, A. (2010). El principio de fe pública registral. Lima: Jurista Editores E.I.R.L.

Lacruz Berdejo, J. L. (2011). Lecciones de derecho inmobiliario registral. Navarra: Civitas - Thomson reuters.

Mendoza Del Maestro, G. (12 de julio de 2015). Recuperado del sitio de internet de Catedra judicial un espacio para compartir el camino a la justicia. Obtenido de http://catedrajudicial.blogspot.com/2015/07/la-ley-n-30313-el-registradorcomo.html

Moisset de Espanés, L. (2015). Publicidad registral (1 ed.). Lima: Sunarp.

Muro P., A. (1997). Manual del registro de la propiedad inmueble: Doctrina, legislación, jurisprudencia, concordancias, diversas directivas y resoluciones expedidas por los RR.PP. Lima: Enmarce.

Nuñez Palomino, G., \& Uchuya Carrasco, H. (2000). Derecho registral doctrina de Roca Sartre. Perú: Azul Grana Editores.

Pasco Arauco, A. (2018). Fraude inmobiliario análisis para una efectiva defensa legal de la propiedad. Lima: Gaceta jurídica.

Resolución del Superintendente Nacional de los registros públicos $\mathrm{N}^{\circ}$ 126-2012SUNARP-SN. (22 de mayo de 2012). Recuperado del sitio de internet del Sistema Peruano de Información Jurídica. Obtenido de http://spijlibre.minjus.gob.pe/normativa_libre/main.asp

Rimascca Huarancca, Á. (2015). El derecho registral: En la jurisprudencia del tribunal registral (Primera edición ed.). Lima: Gaceta Juridica. 
Salgado Padilla, A. F. (2011). Manual de derecho registral. Lima: Cadillo.

Soria Alarcon, M. F. (1997). Estudios de derecho registral. Lima: Palestra.

Soria Alarcon, M. F. (2012). Registros públicos: Los contratos con publicidad ; un recorrido a los 28 años de vigencia del libro IX del Código civil. Lima: Jurista editores.

Tarazona Alvarado, F. (2017). El sistema registral peruano y los principios que lo rigen. Lima: Gaceta Notarial.

Velásquez Jaramillo, L. G. (2004). Bienes (9a ed. ed.). Bogotá: Temis S.A.

Villaro, F. P. (2010). Derecho registral inmobiliario (1a ed. ed.). Buenos Aires: Astrea.

Vivar Morales, E. M. (1992). Derecho registral y notarial. Lima: PUCP. 


\section{ANEXOS}

\section{Anexo 1: Ley $\mathbf{N}^{\circ} 30313$}

Ley $\mathrm{N}^{\circ}$ 30313, publicado en el Diario Oficial El Peruano el 26 de marzo EL PRESIDENTE DE LA REPÚBLICA

POR CUANTO: 
LA COMISIÓN PERMANENTE DEL CONGRESO DE LA REPÚBLICA;

Ha dado la Ley siguiente:

LEY DE OPOSICIÓN AL PROCEDIMIENTO DE INSCRIPCIÓN REGISTRAL EN TRÁMITE Y CANCELACIÓN DEL ASIENTO REGISTRAL POR SUPLANTACIÓN DE IDENTIDAD O FALSIFICACIÓN DE DOCUMENTACIÓN Y MODIFICATORIA DE LOS ARTÍCULOS 2013 Y 2014 DEL CÓDIGO CIVIL Y DE LOS ARTÍCULOS 4 Y 55 Y LA QUINTA Y SEXTA DISPOSICIONES COMPLEMENTARIAS TRANSITORIAS Y FINALES DEL DECRETO LEGISLATIVO 1049

\section{Artículo 1. Objeto de la Ley}

La presente Ley tiene como objeto establecer disposiciones vinculadas a la oposición en el procedimiento de inscripción registral en trámite, la cancelación del asiento registral por suplantación de identidad o falsificación de los documentos presentados a los registros administrados por la Superintendencia Nacional de los Registros Públicos, así como modificar las disposiciones del Código Civil y del Decreto Legislativo del Notariado para prevenir y anular las acciones fraudulentas que afectan la seguridad jurídica.

\section{Artículo 2. Naturaleza del procedimiento de inscripción registral}

El procedimiento de inscripción registral de un título es especial y de naturaleza no contenciosa, con las excepciones previstas en la presente Ley.

Únicamente cabe admitir el apersonamiento de autoridades o funcionarios al procedimiento de inscripción en trámite para plantear su oposición por suplantación de identidad o falsificación de documentos, conforme a lo establecido en el artículo 3 de la presente Ley.

La persona que presenta una solicitud de oposición sin arreglo a lo previsto en la presente Ley no forma parte del procedimiento, debiendo el registrador rechazar de plano dicha oposición, en decisión irrecurrible en sede administrativa.

Artículo 3. Formulación de oposición en el procedimiento de inscripción registral en trámite

3.1 Solo se admite el apersonamiento del notario, cónsul, juez, funcionario público o árbitro al procedimiento de inscripción registral en trámite en los casos de suplantación de identidad o falsificación de documentos, mediante la oposición a este sustentada exclusivamente en la presentación de los siguientes documentos, según corresponda: 
a. Declaración notarial o del cónsul cuando realice función notarial, indicando que se ha suplantado al compareciente o a su otorgante o a sus representantes en un instrumento público protocolar o extraprotocolar. En este último caso, debe dar mérito a la inscripción registral.

b. Declaración notarial o del cónsul cuando realice función notarial, indicando que el instrumento público protocolar o extraprotocolar que aparentemente proviene de su respectivo despacho no ha sido emitido por él. En el caso de los instrumentos extraprotocolares, estos deben dar mérito a la inscripción registral.

c. Oficio del juez, indicando que el parte judicial materia de calificación, que aparentemente proviene de su respectivo despacho, no ha sido expedido por él.

d. Declaración del funcionario público competente mediante oficio de la entidad administrativa, indicando que el documento presentado para su inscripción no ha sido extendido o emitido por la entidad que representa.

e. Declaración del árbitro o presidente del tribunal arbitral, indicando que el laudo arbitral materia de calificación no ha sido expedido por él o por el tribunal arbitral.

Cualquier documento distinto a los antes señalados es rechazado liminarmente, en decisión irrecurrible en sede administrativa.

3.2 En caso se formule oposición en el procedimiento de inscripción registral en trámite, esta solo es presentada ante los Registros Públicos por notario, cónsul, juez, funcionario público o árbitro que emitió alguno de los documentos referidos en los literales a, b, c, d y e del párrafo 3.1, dentro del plazo de vigencia del asiento de presentación.

3.3 No cabe oposición al título inscrito o anotado en la partida registral.

3.4 Formulada la oposición al título presentado sustentada en cualquiera de los documentos a que se refieren los literales a, b, c, d y e del párrafo 3.1, las instancias registrales bajo responsabilidad, previa calificación y verificación, proceden a la tacha del título.

3.5 La persona que denuncie la falsificación de documentos ante notario, cónsul, juez, funcionario público o árbitro, para que se apersone e inicie el procedimiento de oposición con cualquiera de los documentos establecidos en los literales a, b, c, d y e del párrafo 3.1, pone esta denuncia en conocimiento del registrador o del tribunal registral para que, de ser pertinente, se realice la tacha por falsedad documentaria prevista en el Reglamento General de los Registros Públicos. 
3.6 La persona que denuncie la suplantación de identidad ante notario, cónsul, juez, funcionario público o árbitro para que se apersone e inicie el procedimiento de oposición con cualquiera de los documentos establecidos en los literales a, b, c, d y e del párrafo 3.1, pone esta denuncia en conocimiento del registrador o del tribunal registral para que oficie al notario, cónsul, juez, funcionario público o árbitro según corresponda, a fin de verificar la existencia de la denuncia.

\section{Artículo 4. Supuestos especiales de cancelación de asientos registrales}

4.1 El jefe zonal de la Oficina Registral de la Superintendencia Nacional de los Registros Públicos correspondiente es competente para resolver las solicitudes de cancelación de asientos registrales por presunta suplantación de identidad o falsificación de documentos notariales, jurisdiccionales o administrativos, siempre que estén acreditados con algunos de los documentos señalados en los literales a, b, c, d y e del párrafo 3.1 del artículo 3.

4.2 La solicitud de cancelación de asiento registral solo es presentada ante los Registros Públicos por notario, cónsul, juez, funcionario público o árbitro, según corresponda, que emitió alguno de los documentos referidos en los literales a, b, c, d y e del párrafo 3.1 del artículo 3.

4.3 En caso de que se disponga la cancelación del asiento registral, esta se realiza bajo exclusiva responsabilidad del notario, cónsul, juez, funcionario público o árbitro que emitió alguno de los documentos referidos en los literales a, b, c, d y e del párrafo 3.1 del artículo 3.

La decisión del jefe zonal de la Oficina Registral de la Superintendencia Nacional de los Registros Públicos de disponer la cancelación de un asiento registral es irrecurrible en sede administrativa. El plazo para la decisión de disponer la cancelación de un asiento registral se establece en el reglamento de la presente Ley.

\section{Artículo 5. Efectos de la cancelación}

La información contenida en las inscripciones y anotaciones preventivas que han sido canceladas, no perjudica al tercero en los términos establecidos en el artículo 2014 del Código Civil. Tampoco perjudican las inscripciones, anotaciones o los títulos pendientes cuya prioridad registral sea anterior al asiento de cancelación.

\section{Artículo 6. Título formal en las decisiones arbitrales}


La decisión arbitral que sustenta la inscripción o anotación en el registro debe cumplir la formalidad que disponga la Superintendencia Nacional de los Registros Públicos conforme al principio registral de titulación auténtica.

\section{DISPOSICIÓN COMPLEMENTARIA FINAL}

\section{ÚNICA. Reglamentación}

El Poder Ejecutivo reglamenta la presente Ley en un plazo no mayor de noventa días calendario contados a partir de su entrada en vigencia.

\section{DISPOSICIONES COMPLEMENTARIAS MODIFICATORIAS}

PRIMERA. Modificación de los artículos 2013 y 2014 del Código Civil

Modifícanse los artículos 2013 y 2014 del Código Civil en los términos siguientes:

\section{“Artículo 2013. Principio de legitimación}

El contenido del asiento registral se presume cierto y produce todos sus efectos, mientras no se rectifique por las instancias registrales o se declare su invalidez por el órgano judicial o arbitral mediante resolución o laudo firme.

El asiento registral debe ser cancelado en sede administrativa cuando se acredite la suplantación de identidad o falsedad documentaria y los supuestos así establecidos con arreglo a las disposiciones vigentes.

La inscripción no convalida los actos que sean nulos o anulables con arreglo a las disposiciones vigentes".

\section{“Artículo 2014. Principio de buena fe pública registral}

El tercero que de buena fe adquiere a título oneroso algún derecho de persona que en el registro aparece con facultades para otorgarlo, mantiene su adquisición una vez inscrito su derecho, aunque después se anule, rescinda, cancele o resuelva el del otorgante por virtud de causas que no consten en los asientos registrales y los títulos archivados que lo sustentan.

La buena fe del tercero se presume mientras no se pruebe que conocía la inexactitud del registro".

SEGUNDA. Modificación de los artículos 4 y55 del Decreto Legislativo 1049, Decreto Legislativo del Notariado

Modifcanse los artículos 4 y 55 del Decreto Legislativo 1049, Decreto Legislativo del Notariado, en los términos siguientes:

\section{“Artículo 4.- Ámbito territorial}


El ámbito territorial del ejercicio de la función notarial es provincial no obstante la localización distrital que la presente ley determina.

Son nulas de pleno derecho las actuaciones notariales referidas a actos de disposición o gravamen intervivos de bienes inmuebles ubicados fuera del ámbito territorial del notario provincial, sin perjuicio que de oficio se instaure al notario el proceso disciplinario establecido en el Título IV de la presente ley. La presente disposición no se aplica al cónsul cuando realiza funciones notariales.

Cuando el acto de disposición o gravamen comprenda más de un inmueble ubicado en diferentes provincias es competente el notario del lugar donde se encuentre cualquiera de ellos, quedando autorizado para ejercer función notarial fuera de los límites de la provincia para la cual ha sido nombrado".

\section{"Artículo 55.- Identidad del Otorgante}

El notario dará fe de conocer a los otorgantes y/o intervinientes o de haberlos identificado.

Es obligación del notario verificar la identidad de los otorgantes o intervinientes, a través del acceso a la base de datos del Registro Nacional de Identificación y Estado Civil -RENIEC-, en aquellos lugares donde se cuente con acceso a Internet y sea posible para la indicada entidad brindar el servicio de consultas en línea, así como a la base de datos de la Superintendencia Nacional de Migraciones, respecto de la información sobre los extranjeros residentes o no en el país, pudiendo acceder al registro de carnés de extranjería, pasaportes y control migratorio de ingreso de extranjeros, para la verificación de la identidad de los intervinientes mediante la verificación de las imágenes, datos y/o la identificación por comparación biométrica de las huellas dactilares. Cuando el notario lo juzgue conveniente exigirá otros documentos y/o la intervención de testigos que garanticen una adecuada identificación.

Para estos efectos, el ejercicio personal de la función no excluye la colaboración de dependientes del despacho notarial, sin que ello implique la delegación de la función para realizar los actos complementarios o conexos que coadyuven al desarrollo de su labor, bajo la responsabilidad exclusiva del notario.

El notario que cumpliendo los procedimientos establecidos en el presente artículo diere fe de identidad de alguno de los otorgantes, inducido a error por la actuación maliciosa de los mismos o de otras personas, no incurre en responsabilidad. (.)" (*) 
(*) Confrontar con el Artículo 1 del Decreto Legislativo $\mathbf{N}^{\circ}$ 1232, publicado el 26 septiembre 2015.

TERCERA. Modificación de las disposiciones complementarias, transitorias y finales quinta y sexta del Decreto Legislativo 1049, Decreto Legislativo del Notariado

Modifícanse las disposiciones complementarias, transitorias y finales quinta y sexta del Decreto Legislativo 1049, Decreto Legislativo del Notariado, en los términos siguientes:

"Quinta.- En el caso de inscripciones sustentadas en instrumentos notariales protocolares o extraprotocolares presumiblemente falsificados, el notario al que supuestamente se atribuye la actuación notarial deberá presentar la solicitud de anotación preventiva en el diario de la oficina registral dentro de los cinco días hábiles contados desde que tuvo conocimiento, bajo su responsabilidad.

Igual procedimiento le corresponde al notario que tome conocimiento de la falsificación de un instrumento protocolar o extraprotocolar que se le atribuya y se haya insertado en instrumento que diera lugar a la inscripción registral.

La presentación posterior a dicho plazo no constituye una causa de inadmisión o improcedencia de la solicitud del notario ante el Registro.

La anotación preventiva tendrá la vigencia de un año contado a partir de la fecha del asiento de presentación. Si dentro de ese plazo, se anota la demanda judicial o medida cautelar que se refiera a este mismo hecho, dicha anotación judicial se correlacionará con la anotación preventiva y surtirá sus efectos desde la fecha del asiento de presentación de esta última. La interposición de estas acciones judiciales, corresponderá a aquellos que tengan interés legítimo en la nulidad de la inscripción obtenida con el título falsificado.

Vencido el plazo de la anotación preventiva que fuera solicitada por el notario, si no se hubiera anotado la demanda o medida cautelar, dicha anotación preventiva caduca de pleno derecho.

La presente anotación preventiva será procedente aunque el actual titular registral sea un tercero distinto al que adquirió un derecho sobre la base del instrumento notarial presuntamente falsificado".

“Sexta.- En el caso de inscripciones sustentadas en instrumentos públicos protocolares en las que presumiblemente se habría suplantado al o a los otorgantes, o a sus respectivos representantes, el notario ante quien se otorgó dicho instrumento debe presentar la 
solicitud de anotación preventiva en el diario de la oficina registral, dentro de los cinco días hábiles contados desde que tuvo conocimiento, bajo su responsabilidad.

La presentación posterior a dicho plazo no constituye una causa de inadmisión o improcedencia de la solicitud del notario ante el Registro.

La anotación preventiva tendrá la vigencia de un año contado a partir de la fecha del asiento de presentación. Si dentro de ese plazo, se anota la demanda judicial o medida cautelar que se refiera a este mismo hecho, dicha anotación judicial se correlacionará con la anotación preventiva y surtirá sus efectos desde la fecha del asiento de presentación de esta última. La interposición de estas acciones judiciales, corresponderá a aquellos que tengan interés legítimo en la nulidad de la inscripción obtenida con el título falsificado.

Vencido el plazo de la anotación preventiva que fuera solicitada por el notario, si no se hubiera anotado la demanda o medida cautelar, dicha anotación preventiva caduca de pleno derecho.

La presente anotación preventiva será procedente aunque el actual titular registral sea un tercero distinto al que adquirió un derecho sobre la base del instrumento notarial sujeto a la presunta falsificación.

En lo que resulte aplicable, las disposiciones complementarias quinta y sexta de las disposiciones complementarias, transitorias y finales del Decreto Legislativo 1049, Decreto Legislativo del Notariado, se regirán por las disposiciones contenidas en el Texto Único Ordenado del Reglamento General de los Registros Públicos”.

\section{DISPOSICIÓN COMPLEMENTARIA TRANSITORIA}

\section{ÚNICA. Adecuación del Reglamento General de los Registros Públicos}

Encárgase al Poder Ejecutivo, según corresponda, la adecuación del Texto Único Ordenado (TUO) del Reglamento General de los Registros Públicos, aprobado por Resolución del Superintendente Nacional de los Registros Públicos N N 126-2012SUNARP-SN, para el cumplimiento de la presente Ley en un plazo de sesenta días calendario a partir de su entrada en vigencia.

Comuníquese al señor Presidente Constitucional de la República para su promulgación.

En Lima, a los cinco días del mes de marzo de dos mil quince.

ANA MARÍA SOLÓRZANO FLORES

Presidenta del Congreso de la República

NORMAN LEWIS DEL ALCÁZAR 
Segundo Vicepresidente del Congreso

de la República

AL SEÑOR PRESIDENTE CONSTITUCIONAL DE LA REPÚBLICA

POR TANTO:

Mando se publique y cumpla.

Dado en la Casa de Gobierno, en Lima, a los veinticinco días del mes de marzo del año dos mil quince.

OLLANTA HUMALA TASSO

Presidente Constitucional de la República

ANA JARA VELÁSQUEZ

Presidenta del Consejo de Ministros

\section{Anexo 2: DECRETO SUPREMO No 010-2016-JUS}

DECRETO SUPREMO No 010-2016-JUS, publicada en el Diario Oficial El Peruano el 23 de Julio del año 2016. Aprueban el Reglamento de la Ley $\mathbf{N}^{0}$ 30313, Ley de Oposición al Procedimiento de Inscripción Registral en Trámite y Cancelación del Asiento Registral por Suplantación de Identidad o Falsificación de Documentación y Modificatoria de los Artículos 2013 y 2014 del Código Civil y de los Artículos 4 y 55 y la Quinta y Sexta Disposiciones Complementarias Transitorias y Finales del Decreto Legislativo 1049

EL PRESIDENTE DE LA REPÚBLICA 


\section{CONSIDERANDO:}

Que, se ha expedido la Ley $\mathrm{N}^{\mathrm{o}}$ 30313, Ley de oposición al procedimiento de inscripción registral en trámite y cancelación del asiento registral por suplantación de identidad o falsificación de documentación y modificatoria de los artículos 2013 y 2014 del Código Civil y de los Artículos 4 y 55 y la Quinta y Sexta Disposiciones Complementarias Transitorias y Finales del Decreto Legislativo 1049;

Que, la norma precitada regula la oposición en el procedimiento de inscripción registral en trámite y el procedimiento de cancelación del asiento registral por suplantación de identidad o falsificación de los documentos presentados ante la Superintendencia Nacional de los Registros Públicos - SUNARP; y, asimismo, modifica disposiciones del Código Civil y del Decreto Legislativo No 1049 , Decreto Legislativo del Notariado;

Que, el presente Reglamento establece los requisitos y aspectos procedimentales de las figuras jurídicas contempladas en la precitada Ley $\mathrm{N}^{\mathrm{o}} 30313$, a fin de coadyuvar a prevenir y anular las acciones fraudulentas que afectan la seguridad jurídica en los casos de suplantación de identidad o falsificación de los documentos presentados ante la Superintendencia Nacional de los Registros Públicos - SUNARP;

Que, conforme a la Única Disposición Complementaria Final de la Ley № 30313, el Poder Ejecutivo reglamenta esta norma en un plazo no mayor de noventa (90) días calendario contados a partir de su entada en vigencia;

De conformidad con lo dispuesto en el inciso 8 del artículo 118 de la Constitución Política del Perú; la Ley N² 29158, Ley Orgánica del Poder Ejecutivo y la Ley No 30313;

DECRETA:

\section{Artículo 1.- Objeto}

Aprobar el Reglamento de la Ley № 30313, Ley de oposición al procedimiento de inscripción registral en trámite y cancelación del asiento registral por suplantación de identidad o falsificación de documentación y modificatoria de los artículos 2013 y 2014 del Código Civil y de los artículos 4 y 55 y la Quinta y Sexta disposiciones complementarias transitorias y finales del Decreto Legislativo $\mathrm{N}^{\circ} 1049$, cuyo texto consta de setenta (70) artículos, siete (7) disposiciones complementarias finales y dos (2) disposiciones complementarias transitorias, que como anexo forman parte integrante del presente Decreto Supremo.

\section{Artículo 2.- Vigencia}


El Reglamento aprobado entra en vigencia en el plazo de cuarenta y cinco (45) días hábiles contados a partir del día siguiente de la publicación del presente Decreto Supremo en el Diario Oficial El Peruano, a excepción del Capítulo I y el Subcapítulo IV del Capítulo V que entran en vigencia a partir del día siguiente de dicha publicación.

\section{Artículo 3.- Difusión}

A efectos de su difusión, se dispone la publicación del presente Decreto Supremo y el Reglamento en el Portal del Estado peruano (www.peru.gob.pe); en el Portal Institucional del Ministerio de Justicia y Derechos Humanos (www.minjus.gob.pe) y en el Portal Institucional de la Superintendencia Nacional de los Registros Públicos (www.sunarp.gob.pe).

\section{Artículo 4.- Refrendo}

El presente Decreto Supremo es refrendado por la Ministra de Relaciones Exteriores y por el Ministro de Justicia y Derechos Humanos.

Dado en la Casa de Gobierno, en Lima, a los veintidós días del mes de julio del año dos mil dieciséis.

OLLANTA HUMALA TASSO

Presidente de la República

ALDO VÁSQUEZ RÍOS

Ministro de Justicia y Derechos Humanos

ANA MARÍA SÁNCHEZ DE RÍOS

Ministra de Relaciones Exteriores

REGLAMENTO DE LA LEY No 30313, LEY DE OPOSICIÓN AL PROCEDIMIENTO DE INSCRIPCIÓN REGISTRAL EN TRÁMITE Y CANCELACIÓN DEL ASIENTO REGISTRAL POR SUPLANTACIÓN DE IDENTIDAD O FALSIFICACIÓN DE DOCUMENTACIÓN Y MODIFICATORIA DE LOS ARTÍCULOS 2013 Y 2014 DEL CÓDIGO CIVIL Y DE LOS ARTÍCULOS 4 Y 55 Y LA QUINTA Y SEXTA DISPOSICIONES COMPLEMENTARIAS TRANSITORIAS Y FINALES DEL DECRETO LEGISLATIVO 1049

CAPÍTULO I

DISPOSICIONES GENERALES

Artículo 1. Objeto 
El presente Reglamento establece los requisitos y el procedimiento para el trámite de la oposición de inscripción registral y la cancelación de asiento registral previstas en la Ley $N^{o}$ 30313, Ley de oposición al procedimiento de inscripción registral en trámite y cancelación del asiento registral por suplantación de identidad o falsificación de documentación y modificatoria de los artículos 2013 y 2014 del Código Civil y de los Artículos 4 y 55 y la Quinta y Sexta Disposiciones Complementarias Transitorias y Finales del Decreto Legislativo 1049.

\section{Artículo 2. Ámbito de aplicación objetivo}

El presente Reglamento se aplica a todos los registros jurídicos a cargo de la Superintendencia Nacional de los Registros Públicos - SUNARP.

\section{Artículo 3. Ámbito de aplicación subjetivo}

El presente Reglamento se aplica a los siguientes sujetos:

1. La autoridad o funcionario legitimado que solicita la oposición al procedimiento de inscripción registral en trámite o la cancelación del asiento registral irregular por falsificación de documentos o suplantación de identidad.

2. El servidor o funcionario de la SUNARP.

3. El interesado, quien acude ante la autoridad o funcionario legitimado a fin de que solicite la oposición o la cancelación en sede administrativa del asiento registral irregular.

4. El notario, respecto de la anotación preventiva prevista en la Quinta y la Sexta Disposición Complementaria Transitoria y Final del Decreto Legislativo No 1049.

\section{Artículo 4. Naturaleza del procedimiento de inscripción registral}

El procedimiento administrativo de inscripción registral es especial y de naturaleza no contenciosa. No cabe admitir el apersonamiento de terceros al procedimiento ya iniciado, salvo los supuestos de suplantación de identidad o falsificación de documentos en los que se admite la oposición, conforme a lo regulado en la Ley $\mathrm{N}^{\mathrm{0}} 30313$ y en el presente Reglamento.

\section{Artículo 5. Abreviaturas}

Para los efectos del presente Reglamento, se entiende por:

1. RENIEC: Registro Nacional de Identificación y Estado Civil.

2. Ley No 27444: Ley del Procedimiento Administrativo General.

3. Decreto Legislativo No 1049: Decreto Legislativo del Notariado.

4. Ley No 26366: Ley de creación del Sistema Nacional de los Registros Públicos y de la Superintendencia de los Registros Públicos. 
5. Ley $\mathrm{N}^{\mathrm{0}}$ 30313: Ley de oposición al procedimiento de inscripción registral en trámite y cancelación del asiento registral por suplantación de identidad o falsificación de documentación y modificatoria de los artículos 2013 y 2014 del Código Civil y de los artículos 4 y 55 y la Quinta y Sexta disposiciones complementarias transitorias y finales del Decreto Legislativo No 1049.

6. TUO del Reglamento General de los Registros Públicos: Texto Único Ordenado del Reglamento General de los Registros Públicos, aprobado por Resolución del Superintendente Nacional de los Registros Públicos No 126-2012-SUNARP-SN o norma que lo sustituya.

\section{Artículo 6. Glosario de términos}

Para los efectos del presente Reglamento, se entiende por:

1. Acta de identificación: Es el formato mediante el cual se acredita la identificación de quien se apersona ante la Oficina Registral para presentar la solicitud de oposición al procedimiento de inscripción registral en trámite o la solicitud de cancelación de un asiento de inscripción irregular.

2. Asiento de cancelación: Es la inscripción que se utiliza para cancelar otro asiento con la presunción de extinción del derecho publicitado.

3. Asiento registral irregular: Es aquella inscripción sustentada en el título que contiene un instrumento falsificado total o parcialmente, o cuando en su elaboración se ha producido una suplantación de identidad del otorgante o compareciente.

4. Autoridad o funcionario legitimado: Es el notario, cónsul, juez, funcionario público o árbitro, quienes están legitimados para solicitar la oposición al procedimiento de inscripción registral en trámite y la cancelación del asiento registral irregular por suplantación de identidad o falsificación de documento.

5. Diario: Es el sistema informático existente en cada Oficina Registral que permite consignar de manera cronológica la presentación de los títulos de acuerdo a los requisitos previstos en el TUO del Reglamento General de los Registros Públicos y demás normas reglamentarias que emita la SUNARP.

6. Instancia registral: Es aquella conformada por el registrador y el Tribunal Registral, cuando corresponda.

7. Jefe zonal: Es el servidor civil de mayor jerarquía en cada zona registral u órgano desconcentrado de la SUNARP. 
8. Mesa de partes: Es el área de la Oficina Registral destinada a recibir documentos vinculados a un procedimiento de inscripción registral en trámite. No genera asiento de presentación.

9. Módulo "Sistema Notario": Es un sistema de información a través del cual el notario obligatoriamente incorpora, cambia o retira a sus dependientes, sellos, firmas u otra información que sea habilitada en dicha aplicación para coadyuvar a contrarrestar el riesgo de la presentación de documentos notariales falsificados.

10. Oficina Registral: Es la encargada de prestar los servicios de inscripción y publicidad registral de los diversos actos y derechos inscribibles.

11. Registros: Son aquellos registros jurídicos a cargo de la SUNARP previstos en el artículo 2 de la Ley $N^{\circ} 26366$ y en otras normas especiales.

12. Registro de Propiedad Inmueble y Registro de Bienes Muebles: Son aquellos registros jurídicos a cargo de la SUNARP donde se inscriben actos o derechos sobre el bien mueble o inmueble.

13. Título en trámite: Es el instrumento que contiene el acto o derecho inscribible presentado en cualquier Oficina Registral de la SUNARP que se encuentra en proceso de calificación por la instancia registral.

14. Trámite documentario: Es el área de la oficina registral encargada de recibir la documentación en general.

\section{CAPÍtULO II}

\section{OPOSICIÓN Y CANCELACIÓN EN SEDE ADMINISTRATIVA}

\section{Artículo 7. Supuestos para formular la oposición o cancelación}

7.1 La autoridad o funcionario legitimado formula la oposición o la cancelación, según corresponda, únicamente en los siguientes supuestos:

1. Suplantación de identidad en el instrumento público protocolar extendido ante el notario o cónsul.

2. Suplantación de identidad en el instrumento público extraprotocolar, siempre que el firmante se haya identificado ante el notario o cónsul.

3. Falsificación de instrumento público supuestamente expedido por la autoridad o funcionario legitimado.

4. Falsificación de documento inserto o adjunto en el instrumento público expedido por la autoridad o funcionario legitimado que sea necesario para la inscripción registral del título. 
5. Falsificación de la decisión arbitral supuestamente expedida por el árbitro.

7.2 La formulación de una oposición o cancelación no puede tratar sobre supuestos de falsedad ideológica, quedando a salvo el derecho del perjudicado para acudir al órgano jurisdiccional correspondiente.

\section{Artículo 8. Deberes de la autoridad o funcionario legitimado}

La autoridad o funcionario legitimado tiene los siguientes deberes:

1. Atender oportunamente la denuncia de falsificación de documentos o suplantación de identidad presentada por el interesado.

2. Verificar los hechos señalados en la denuncia de falsificación de documentos o suplantación de identidad presentado por el interesado.

3. Solicitar la oposición de título en trámite o cancelación de asiento registral, de oficio o en mérito a la presentación de la denuncia, dentro de los plazos establecidos en el presente Reglamento.

4. Responder la comunicación de la instancia registral dentro de los plazos establecidos en el presente Reglamento.

\section{Artículo 9. Silencio administrativo negativo}

La oposición al procedimiento de inscripción registral en trámite y la cancelación en sede administrativa de un asiento registral irregular se encuentran sujetas al silencio administrativo negativo de acuerdo a lo previsto en la Primera Disposición Complementaria y Final de la Ley No 29060, Ley del Silencio Administrativo, quedando expedito el derecho de interponer las acciones judiciales correspondientes.

\section{CAPÍTULO III}

CONOCIMIENTO DE LA PRESENTACIÓN DE UN TÍTULO Y LA PRESENTACIÓN DE LA DENUNCIA

\section{SUBCAPÍTULO I}

\section{CONOCIMIENTO DE LA PRESENTACIÓN DE UN TÍTULO}

\section{Artículo 10. Conocimiento de la presentación al registro de un título}

El interesado conoce de la presentación de uno o más títulos ingresados al registro a través del servicio de Alerta Registral, sin perjuicio de que pueda tomar conocimiento por cualquier otro medio.

\section{Artículo 11. Servicio de "Alerta Registral"}


La Alerta Registral es un servicio gratuito por el cual se brinda información, mediante correo electrónico o mensaje de texto, sobre la presentación al registro de uno o más títulos respecto a una determinada partida registral.

\section{Artículo 12. Formas de suscripción al Servicio de Alerta Registral}

El servicio de Alerta Registral se brinda de las siguientes formas:

1. De oficio: Es aquella efectuada por la SUNARP cuando se inscribe una transferencia de propiedad en el Registro de Predios o en el Registro Propiedad Vehicular. Para tal efecto, en el formulario de solicitud de inscripción registral se debe consignar el correo electrónico o el número de teléfono móvil del adquirente, aun cuando este ya se encuentre suscrito al servicio de Alerta Registral.

2. A solicitud: Es aquella efectuada por el interesado mediante la suscripción del formulario virtual desde el Portal Institucional de la SUNARP.

\section{Artículo 13. Lectura del título en trámite}

El interesado que conoce, mediante el Servicio de Alerta Registral o por cualquier otro medio, de la presentación de uno o más títulos vinculados a una partida registral determinada, puede acceder a la información del título en trámite a través de su lectura, previo pago de los derechos registrales.

\section{Artículo 14. Expedición de copia de título en trámite}

Tratándose de la solicitud de oposición, el interesado puede solicitar copia de los documentos que conforman el título en trámite en la partida registral, conforme al TUO de la Ley $\mathrm{N}^{\mathrm{o}}$ 27806, Ley de Transparencia y Acceso a la Información Pública, aprobado por el Decreto Supremo No 043-2003-JUS. Para tal efecto, el encargado de brindar la información expide la copia certificada del título en trámite en un plazo no mayor de dos (2) días hábiles contados desde el día siguiente de la presentación de dicha solicitud.

\section{SUBCAPÍTULO II}

\section{LA DENUNCIA SOBRE FALSIFICACIÓN DE DOCUMENTOS O SUPLANTACIÓN DE IDENTIDAD}

\section{Artículo 15. La denuncia}

La denuncia es la solicitud del interesado dirigida a la autoridad o funcionario legitimado para comunicar la existencia de un asiento registral irregular o de un procedimiento de inscripción registral en trámite sustentado en título que adolece de falsificación de documento o suplantación de identidad.

\section{Artículo 16. Contenido de la denuncia}


La denuncia debe contener la indicación de los hechos, la información que permita su constatación, así como el aporte de la evidencia o cualquier otro elemento que permita verificar la falsificación del documento o la suplantación de identidad.

\section{Artículo 17. Lugar de presentación de la denuncia}

La denuncia se presenta en el domicilio de la autoridad o funcionario legitimado, de la siguiente manera:

1. En el caso del notario: Se presenta en el domicilio del despacho notarial. En caso de cese del notario se presenta en el domicilio del Colegio de Notarios correspondiente.

2. En el caso del cónsul: Se presenta en la mesa de partes del domicilio del Ministerio de Relaciones Exteriores o en el domicilio del consulado.

3. En el caso del juez: Se presenta en la mesa de partes del domicilio de la Corte Superior del Distrito Judicial al que pertenece el juez o en el domicilio de su despacho judicial.

4. En el caso del funcionario público: Se presenta en la mesa de partes del domicilio de la entidad a la que pertenece.

5. En el caso de arbitraje institucional: Se presenta en el domicilio del centro de arbitraje.

6. En el caso del árbitro ad-hoc: Se presenta en el domicilio que conste en el RENIEC.

\section{Artículo 18. Plazo de atención de la denuncia presentada}

Los plazos para la atención de la denuncia presentada son los siguientes:

1. En el caso de la oposición de inscripción registral: La autoridad o funcionario legitimado se pronuncia sobre la denuncia en el plazo máximo de cinco (5) días hábiles contados desde el día siguiente de su presentación.

2. En el caso de la cancelación de asiento registral: La autoridad o funcionario legitimado se pronuncia sobre la denuncia en el plazo máximo de diez (10) días hábiles contados desde el día siguiente de su presentación. Tratándose de un supuesto de cese, el plazo se interrumpe y se computa a partir de la designación por el Colegio de Notarios del notario que asume la competencia para evaluar y formular la denuncia.

Artículo 19. Acciones de la autoridad o funcionario legitimado respecto de la denuncia

19.1 Una vez que la autoridad o funcionario legitimado recibe la denuncia, procede a realizar las siguientes acciones: 
1. En el caso de que se trate de un supuesto de falsificación de documento total o parcial, entre otras acciones, verifica la firma, rúbrica, signo, sellos de seguridad o confronta la información con el instrumento matriz, según corresponda.

2. En el caso de que se trate de un supuesto de suplantación de identidad, el notario o cónsul evalúa la denuncia a través de los siguientes documentos: partida de defunción o certificado de movimiento migratorio del supuesto otorgante o compareciente del acto, que acrediten indubitablemente la imposibilidad material de su intervención en el instrumento, o cualquier otro medio que estime pertinente.

19.2 De verificarse la existencia del supuesto de falsificación de documentos o suplantación de identidad contenido en la denuncia, la autoridad o funcionario legitimado procede a formular la solicitud de oposición o cancelación de asiento registral.

Artículo 20. Demora injustificada frente a la denuncia formulada por el interesado

20.1 Si la autoridad o funcionario legitimado no emite pronunciamiento en el plazo previsto en el presente Reglamento, el interesado puede comunicar dicha situación adjuntando el cargo de la presentación de la denuncia, en los siguientes términos:

1. En el caso de notario: Ante el Tribunal de Honor del Colegio de Notarios.

2. En el caso del cónsul: Ante el Ministerio de Relaciones Exteriores, conforme a la Ley No 28091, Ley del Servicio Diplomático de la República.

3. En el caso del juez: Ante la Oficina de Control de la Magistratura.

4. En el caso del funcionario público: Ante el superior jerárquico o registrarlo en el libro de reclamaciones.

5. En caso del árbitro: Ante la institución arbitral que lo nombró o, en su defecto, ante la Cámara de Comercio correspondiente.

20.2 La comunicación precitada se formula sin perjuicio de las acciones judiciales que podrían resultar pertinentes promover.

Artículo 21. Actuación de oficio por la autoridad o funcionario legitimado para la oposición del título en trámite

Cuando la autoridad o funcionario legitimado toma conocimiento de la falsificación de documento o de la suplantación de identidad en un instrumento que haya expedido o autorizado, por un medio distinto a la presentación de la denuncia, se encuentra obligado a solicitar de oficio la oposición o cancelación, según sea el caso.

Artículo 22. Desestimación de la denuncia en el caso de cancelación 
Cuando la autoridad o funcionario legitimado desestime la denuncia por no existir mérito suficiente para promover la cancelación de un asiento registral irregular, en los términos de la Ley № 30313 y el presente Reglamento, el interesado tiene expedito su derecho de solicitar judicialmente la nulidad del asiento registral.

\section{Artículo 23. Cancelación en sede judicial del asiento registral irregular}

Para obtener la cancelación en sede judicial de un asiento registral irregular, no es requisito previo haber solicitado ante la autoridad o funcionario legitimado la cancelación en sede administrativa.

\section{SUBCAPÍTULO III}

CONOCIMIENTO DE LA INSTANCIA REGISTRAL DE LA DENUNCIA PRESENTADA POR EL INTERESADO ANTE LA AUTORIDAD O FUNCIONARIO PARA FORMULAR OPOSICIÓN

Artículo 24. Comunicación de la denuncia a la instancia registral en el caso de oposición del título en trámite

24.1. El interesado comunica a la instancia registral la presentación de la denuncia de conformidad con los párrafos 3.5 y 3.6 del artículo 3 de la Ley $N^{o} 30313$. Para tal efecto, debe adjuntar la reproducción certificada notarialmente o copia autenticada por fedatario institucional de la oficina registral de la denuncia en la que se advierta la constancia de recepción que acredite su presentación previa ante la autoridad o funcionario legitimado correspondiente.

24.2. La presentación de la comunicación precitada se efectúa en mesa de partes, o la que haga sus veces, de la oficina registral donde se encuentra el título que dio inicio al procedimiento de inscripción registral en trámite. Si el título se encuentra apelado ante el Tribunal Registral, se presenta en la oficina de trámite documentario o la que haga sus veces.

24.3. Cuando la comunicación al Registro no contenga la documentación indicada en el presente artículo, es rechazada liminarmente por el servidor de mesa de partes o trámite documentario, según corresponda, o en su defecto por la instancia registral.

Artículo 25. Acciones de la instancia registral al tomar conocimiento de la denuncia de oposición al título en trámite

Ante el conocimiento de la denuncia, en el plazo máximo de tres (3) días hábiles la instancia registral oficia a la autoridad o funcionario legitimado en los domicilios 
indicados en el artículo 17 del presente Reglamento, para que cumpla con atenderla debidamente.

Artículo 26. Suspensión y prórroga de la vigencia del asiento de presentación del título en trámite

El asiento de presentación del título en trámite se suspende o se prorroga en los siguientes términos:

1. En el caso de que se oficie a la autoridad o funcionario legitimado, el registrador suspende la vigencia del asiento de presentación por un plazo máximo de veinte (20) días hábiles contados desde el día siguiente de la remisión del oficio a la autoridad o funcionario legitimado.

2. En el caso de que se oficie a la autoridad o funcionario legitimado, el Tribunal Registral prorroga el plazo para resolver el recurso de apelación por veinte (20) días hábiles adicionales contados desde el día siguiente de la remisión del oficio a la autoridad o funcionario legitimado.

\section{Artículo 27. Plazo de atención del oficio de la instancia registral}

27.1. La autoridad o funcionario legitimado debe responder el oficio de la instancia registral en el plazo máximo de diez (10) días hábiles, contados desde el día siguiente de la recepción de la comunicación.

27.2. En caso la respuesta de la autoridad o funcionario legitimado se presente con posterioridad al plazo indicado en el párrafo precedente, dicha circunstancia no impide la evaluación por el registrador siempre que el título no haya sido inscrito. Ello sin perjuicio de la aplicación de los mecanismos de responsabilidad que corresponda.

Artículo 28. Acciones de la instancia registral ante la respuesta u omisión de la autoridad o funcionario legitimado en el caso de oposición

28.1. Cuando la autoridad o funcionario legitimado responde formulando oposición, el registrador o Tribunal Registral estima la solicitud y dispone la tacha del título, previa calificación de la oposición.

28.2. Cuando la autoridad o funcionario legitimado no responde o desestima el supuesto de falsificación o suplantación de identidad del título en trámite, el registrador levanta la suspensión y continúa con la calificación registral.

\section{CAPÍTULO IV}

OPOSICIÓN DE TÍTULO EN TRÁMITE

\section{Artículo 29. Formalidad de la oposición}


La oposición en el procedimiento de inscripción registral en trámite se solicita por escrito y se presenta conjuntamente con el formulario de solicitud de oposición aprobado por la SUNARP.

\section{Artículo 30. Competencia para conocer la oposición}

La instancia registral es competente para conocer la oposición de un título en trámite, la cual está conformada por el registrador que conoce del procedimiento de inscripción registral del título que ha sido materia de oposición; y, por el Tribunal Registral, en el caso de que dicho título haya sido apelado.

\section{Artículo 31. Efecto de la oposición}

La oposición que haya sido estimada por la instancia registral, previa calificación y verificación, tiene como efecto la tacha del título por falsificación de documentos o suplantación de identidad, según corresponda.

\section{Artículo 32. Formulación de la oposición al título en trámite}

32.1 La oposición se sustenta exclusivamente en la presentación de los documentos señalados en el párrafo 3.1 de la Ley No 30313.

32.2 Sin perjuicio de lo anterior, la oposición también debe contener la siguiente información:

1. Datos de identificación del funcionario o autoridad, con indicación de su domicilio.

2. Indicación de la fecha y número del título materia de oposición.

3. Sello y firma del funcionario o autoridad que formula la oposición.

\section{Artículo 33. Formas de presentación de la oposición}

La autoridad o funcionario legitimado presenta la oposición en los siguientes términos:

1. Si la oposición es solicitada por el notario, debe ser presentada por él o su dependiente acreditado ante el registro a través del módulo "Sistema Notario".

2. Si la oposición es solicitada por el cónsul, debe ser ingresada por el presentante del Ministerio de Relaciones Exteriores acreditado ante el Registro.

3. Si la oposición es solicitada por el árbitro, debe ser presentada personalmente ante el Registro.

4. Si la oposición es solicitada por el juez o el funcionario público, puede ser presentada al Registro por cualquier persona.

\section{Artículo 34. Oportunidad para presentar la oposición}

34.1 La autoridad o funcionario legitimado debe solicitar la oposición a un título en trámite antes de su inscripción. 
34.2 Si la oposición se presenta dentro de los últimos cinco (5) días hábiles de vigencia del asiento de presentación del título, este se prorroga automáticamente por quince (15) días hábiles adicionales.

\section{Artículo 35. Lugar de presentación de la oposición solicitada ante el registrador}

35.1 La solicitud de oposición de la autoridad o funcionario legitimado se presenta en mesa de partes, o la que haga sus veces, de la oficina registral donde se encuentra el título del procedimiento de inscripción registral en trámite que es materia de calificación por el registrador.

35.2 Cuando se presenta la solicitud de oposición en una Oficina Registral distinta a la competente, se aplica el procedimiento de oficina receptora y oficina de destino previsto por la SUNARP, sin que ello genere el pago de una tasa registral por el servicio de mensajería.

\section{Artículo 36. Lugar de presentación de la oposición ante el Tribunal Registral}

Cuando el título que dio inicio al procedimiento de inscripción registral en trámite se encuentre apelado ante el Tribunal Registral, la solicitud de oposición de la autoridad o funcionario legitimado se presenta en la oficina de trámite documentario o la que haga sus veces. En ningún caso, se admite la presentación a través del diario o mesa de partes.

\section{Artículo 37. Supuestos de rechazo liminar de la oposición}

37.1 La oposición es rechazada liminarmente en cualquiera de los siguientes supuestos:

1. Cuando no ha sido suscrito por la autoridad o funcionario legitimado.

2. Cuando se sustente en documento distinto a los señalados en el artículo 3.1 de la Ley $\mathrm{N}^{\circ} 30313$.

3. Cuando no ha sido presentada por las personas indicadas en el artículo 33 del presente Reglamento.

4. Cuando no se trate de los supuestos señalados en el artículo 7 del presente Reglamento.

37.2 En el rechazo liminar, la documentación que fuera ingresada al registro no forma parte del título que dio inicio al procedimiento de inscripción registral en trámite y se procede a su devolución. Tampoco procede la prórroga automática a que se refiere el párrafo 34.2 del presente Reglamento.

Artículo 38. Actuaciones del servidor de mesa de partes o trámite documentario 
Cuando la autoridad o funcionario legitimado presente la oposición, el servidor de mesa de partes o trámite documentario, según corresponda, realiza las siguientes actuaciones:

1. Identifica a la persona a través del lector biométrico del RENIEC. Si por razones de fuerza mayor o caso fortuito no se puede utilizar dicha herramienta informática, se debe extender el acta de identificación aprobada por la SUNARP.

2. Verifica que la solicitud de oposición haya sido presentada por las personas autorizadas conforme al artículo 33 del presente Reglamento.

\section{Artículo 39. Actuaciones de la instancia registral}

39.1. Cuando habiendo sido admitida, la solicitud de oposición no cumpla todos los requisitos señalados en el artículo 32.2 del presente Reglamento y/o se requiera verificar la autenticidad para el caso de la solicitud del Juez o funcionario público, la instancia registral debe solicitar la subsanación del defecto advertido y/o la confirmación de su autenticidad.

39.2 En el supuesto anterior, la autoridad o funcionario legitimado debe subsanar en el plazo máximo de veinte (20) días hábiles contados desde el día siguiente de la recepción de la solicitud de subsanación de la instancia registral. Las notificaciones se realizan en el domicilio señalado en la solicitud de la oposición, o en su defecto, se aplican los criterios previstos en el artículo 17 del presente Reglamento.

\section{Artículo 40. Falta de respuesta de la autoridad o funcionario legitimado}

40.1. En caso que el notario, cónsul o árbitro no responda en el plazo de veinte (20) días hábiles mencionado en el artículo 39.2 el presente Reglamento, la instancia registral considera como no presentada la solicitud de oposición, sin perjuicio de la aplicación de los mecanismos de responsabilidad que corresponda.

40.2 En el supuesto anterior, la solicitud de oposición no forma parte del título que dio inicio al procedimiento de inscripción registral en trámite y se procede a su devolución.

40.3. En caso que el juez o funcionario público no responda en el plazo de veinte (20) días hábiles, sin perjuicio de los mecanismos de responsabilidad que corresponda aplicar por dicha omisión, el servidor de la SUNARP se apersona a su despacho con la finalidad de verificar la autenticidad de la oposición presentada y/o subsanar los defectos advertidos.

\section{Artículo 41. Suspensión de la vigencia del asiento de presentación}


41.1. En los casos que la oposición no cumpla todos los requisitos previstos en el artículo 32.2, el registrador suspende la vigencia del asiento de presentación del título por un plazo máximo de cuarenta (40) días hábiles.

41.2. Vencido el plazo de cuarenta (40) días hábiles o recibida la respuesta de la autoridad o funcionario legitimado, se levanta la suspensión precitada y se continúa la calificación del título en el plazo de la vigencia del asiento de presentación.

41.3. En los casos que la oposición no cumpla todos los requisitos previstos en el artículo 32.2 y el título se encuentre apelado ante el Tribunal Registral, corresponde prorrogar el plazo para resolver el recurso de apelación por cuarenta (40) días hábiles.

\section{Artículo 42. Decisión de la instancia registral}

Una vez que se haya verificado el cumplimiento de los requisitos de la solicitud de oposición, el registrador o el Tribunal Registral según corresponda, se encuentran facultados para:

1. Estimar la oposición solicitada por la autoridad o funcionario legitimado y proceder a tachar el título conforme a lo establecido en el TUO del Reglamento General de los Registros Públicos.

2. Desestimar la oposición, cuando considere que no existe mérito para ello o cuando se incurra en alguno de los supuestos de rechazo liminar previsto en el artículo 37 del presente Reglamento.

\section{Artículo 43. Apelación de la decisión de la instancia registral}

La decisión del registrador sobre el pedido de oposición es irrecurrible en sede administrativa.

\section{Artículo 44. Notificación de la decisión de la instancia registral}

44.1. La tacha por falsificación de documentos como consecuencia de la presentación de la oposición se notifica de acuerdo a lo previsto en el TUO del Reglamento General de los Registros Públicos.

44.2. La decisión que desestima la oposición se notifica en el domicilio señalado en el escrito correspondiente. En defecto de ello, se aplican los criterios previstos en el artículo 17 el presente Reglamento.

\section{CAPÍtULLO V}

CANCELACIÓN DE UN ASIENTO REGISTRAL IRREGULAR SUBCAPÍTULO I PROCEDIMIENTO 


\section{Artículo 45. Competencia para resolver la cancelación}

El Jefe Zonal es competente para resolver la solicitud de cancelación en sede administrativa de un asiento registral irregular, conforme a la Ley № 30313.

\section{Artículo 46. Efecto de la cancelación}

La cancelación tiene por objeto dejar sin efecto un asiento registral irregular extendido en cualquiera de los registros a cargo de la SUNARP.

\section{Artículo 47. Responsabilidad de la autoridad o funcionario legitimado}

La cancelación de un asiento registral irregular se realiza bajo exclusiva responsabilidad de la autoridad o funcionario legitimado que emite alguno de los documentos señalados en el artículo 3.1 de la Ley $N^{\circ} 30313$, dentro del ámbito de su competencia.

\section{Artículo 48. La solicitud de cancelación respecto del tercero registral}

48.1 La cancelación procede aun cuando el titular registral actual sea un tercero distinto a aquel que adquirió el derecho sobre la base de un asiento registral irregular. En este caso, dicho titular registral no se ve perjudicado siempre que cumpla con las condiciones establecidas en el artículo 2014 del Código Civil.

48.2 La cancelación en sede administrativa tampoco perjudica los títulos pendientes cuya prioridad registral sea anterior al asiento de cancelación.

\section{Artículo 49. Presentación de la solicitud de cancelación}

49.1 En el caso que la falsificación o la suplantación de identidad se configuren sobre un instrumento notarial, la solicitud de cancelación debe ser presentada directamente por el propio notario o su dependiente debidamente acreditado ante el Registro.

En caso de vacaciones o licencia, el notario encargado del oficio notarial es responsable de tramitar la denuncia y formular la solicitud de cancelación del asiento registral irregular. Para tal efecto, debe presentar ante los registros la resolución expedida por el Colegio de Notarios que acredite su encargo.

En caso de cese de un notario, mientras el Colegio de Notarios se encargue del cierre de sus registros o los archivos notariales hayan sido transferidos al Archivo General de la Nación o a los archivos departamentales, el interesado puede solicitar ante dicho cuerpo colegiado su pedido de cancelación, debiendo el Colegio de Notarios al cual pertenezca el notario cesado, designar en un plazo no mayor de tres (3) días hábiles al notario responsable de tramitar la denuncia. Para tal efecto debe presentar ante los registros la resolución expedida por el Colegio de Notarios que acredita su designación. En caso 
exista notario administrador del acervo documentario, este será el competente para evaluar y formular la denuncia.

49.2 Cuando la falsificación o la suplantación de identidad se configuren sobre un instrumento consular, la solicitud de cancelación debe ser ingresada por el presentante del Ministerio de Relaciones Exteriores acreditado ante el Registro.

49.3 Cuando la falsificación se configure sobre un instrumento que contenga la decisión arbitral, la solicitud de cancelación solo puede ser presentada ante el Registro por el propio árbitro o cualquiera de los miembros del Tribunal Arbitral que emitió la decisión arbitral que obra inscrita.

49.4 Cuando la falsificación se configure sobre una decisión judicial o un acto administrativo, el juez o funcionario público deben oficiar a la Oficina Registral la solicitud de cancelación del asiento registral irregular. Dicha solicitud de cancelación podrá ser presentada al Registro por cualquier persona.

\section{Artículo 50. Formulación de la cancelación}

50.1 Conforme al párrafo 4.1 de Ley $N^{\circ} 30313$, la cancelación de un asiento registral siempre está acreditada con algunos de los documentos señalados en su artículo 3.1.

50.2 Sin perjuicio de lo anterior, la solicitud de cancelación también debe indicar:

1. Nombres y apellidos de la autoridad o funcionario legitimado

2. Número de documento de identidad de la autoridad o funcionario legitimado.

3. Domicilio legal de la autoridad o funcionario legitimado.

4. La causal de falsificación o suplantación de identidad que ha generado el asiento registral irregular que se pretende cancelar.

5. El número de la partida registral donde obra extendido el asiento que se pretende cancelar.

6. Los documentos aportados por el interesado y demás actuaciones realizadas por la autoridad o funcionario legitimado.

50.3 No se requiere abonar derechos registrales para presentar ni inscribir la solicitud de cancelación.

\section{Artículo 51. Oficina Registral competente y de destino de la solicitud de cancelación}

51.1 La Oficina Registral competente es aquella donde tenga su sede principal el Jefe de la Zona Registral, quien resolverá la solicitud de cancelación del asiento registral irregular. 
51.2 Cuando la cancelación se presente en una Oficina Registral distinta a la que corresponde, se aplica el procedimiento de oficina receptora y oficina de destino previsto por la SUNARP, sin que ello genere el pago de tasa registral por el servicio de mensajería.

51.3 En caso que el personal del diario genere por error un asiento de presentación de cancelación en una oficina que no corresponda, debe proceder en el día a rectificar y encauzar la solicitud a la oficina correcta. En el caso que el registrador detecte dicho error al momento de la calificación de la solicitud de cancelación debe tachar el título.

\section{Artículo 52. Actuaciones del personal encargado de la oficina del diario}

En todos los casos, el servidor encargado de la oficina del diario debe identificar al presentante a través del lector biométrico del RENIEC, salvo que por razones de fuerza mayor o caso fortuito no pueda utilizar dicha herramienta. En este último caso, el encargado de la oficina de diario debe utilizar el formato de acta de identificación aprobado por la SUNARP.

\section{Artículo 53. Admisibilidad y rechazo liminar de la solicitud de cancelación}

53.1 Cuando la solicitud de cancelación no cumpla lo establecido en el artículo 50.2 el presente Reglamento, el Jefe Zonal oficia a la autoridad o funcionario legitimado para que subsane el defecto advertido en el plazo de diez (10) días hábiles.

53.2 El rechazo liminar de la solicitud de cancelación se aplica solo cuando esta ha sido presentada por una persona distinta a la autoridad o funcionario legitimado. En los demás casos, el servidor encargado de la oficina del diario se encuentra prohibido de rechazar de plano una solicitud de cancelación.

53.3 En caso que lo solicite una persona distinta a la autoridad o funcionario legitimado y por error dicha solicitud haya ingresado por el diario de una Oficina Registral, el registrador formula la tacha del título.

\section{Artículo 54. Supuestos de improcedencia de la solicitud de cancelación}

54.1 La solicitud de cancelación se declara improcedente cuando:

1. Es formulada por una persona que no tiene la condición de autoridad o funcionario legitimado.

2. Cuando en la partida registral conste una medida cautelar que cuestione el título que dio mérito a la extensión del asiento registral irregular.

3. Cuando haya transcurrido el plazo de un (1) año, al que se refiere el artículo 62 el presente Reglamento.

4. Cualquier otro supuesto que para tal efecto disponga la SUNARP. 
54.2 La resolución jefatural que dispone la improcedencia no impide que se vuelva a presentar la solicitud de cancelación a través de un nuevo título.

\section{Artículo 55. Trámite de la solicitud de cancelación por el registrador}

55.1 Una vez que la solicitud de cancelación haya sido admitida, el registrador la deriva de forma inmediata al jefe zonal y dispone la suspensión de la vigencia del asiento de presentación del título hasta que se emita la resolución del jefe zonal.

55.2 Una vez emitida la resolución jefatural que dispone la cancelación del asiento registral irregular, el registrador tiene un plazo de cinco (5) días hábiles para extender el asiento cancelatorio respectivo. En el caso de que la cancelación sea denegada, el registrador tiene un plazo de tres (3) días hábiles para formular la tacha que corresponda.

Artículo 56. Suspensión del asiento de presentación cuando la solicitud de cancelación se encuentra en trámite en el Registro de Personas Jurídicas o en el Registro de Mandatos y Poderes

56.1. Si la solicitud de cancelación se encuentra en trámite en el Registro de Mandatos y Poderes o en el Registro de Personas Jurídicas, y existe en trámite un título en el Registro de Bienes referido a un acto de disposición o gravamen del bien vinculado al asiento registral irregular, el registrador del Registro de Bienes suspende la calificación hasta que se extienda el asiento cancelatorio.

56.2. Una vez extendido el asiento cancelatorio en el Registro de Mandatos y Poderes o en el Registro de Personas Jurídicas, el registrador del Registro de Bienes, de oficio o a petición de parte, formula la tacha del título correspondiente.

56.3. En el caso que se desestime la solicitud para cancelar el asiento registral irregular, el registrador del Registro de Bienes continúa con la calificación ordinaria del título.

\section{SUB CAPÍTULO II}

\section{ACTUACIONES DEL JEFE ZONAL EN EL PROCEDIMIENTO DE CANCELACIÓN}

\section{Artículo 57. Actuaciones del Jefe Zonal}

57.1. Al recibir la solicitud de cancelación, en el plazo de siete (7) días hábiles, el Jefe Zonal debe verificar lo siguiente:

1. El cumplimiento de los requisitos en el contenido de la solicitud, previstos en el artículo 50 del presente Reglamento.

2. Que la solicitud no esté comprendida en alguno de los supuestos de improcedencia previstos en el artículo 54 del presente Reglamento. 
57.2. Transcurrido el plazo a que se refiere el párrafo 53.1 del presente Reglamento sin que se haya subsanado el defecto advertido, el Jefe Zonal declara inadmisible la solicitud de cancelación y el registrador formula la tacha del título que corresponda.

57.3. En aquellos casos en que la falsificación se configure sobre una decisión judicial o un acto administrativo, el Jefe Zonal debe remitir un oficio solicitando se confirme la autenticidad de la solicitud de cancelación. El juez o funcionario público, bajo responsabilidad, deben responder en un plazo máximo de treinta (30) días hábiles contados desde el día siguiente a la recepción de la solicitud formulada por el Jefe Zonal.

57.4. Cuando no se requiera oficiar o se haya recibido la respuesta del oficio confirmando la autenticidad de la solicitud de cancelación, el Jefe Zonal notifica en forma inmediata al titular registral vigente en la partida del asiento registral irregular, a fin de que pueda contradecir la solicitud de cancelación.

57.5. La notificación al titular registral se efectúa en el domicilio que aparezca en el RENIEC y en el que figure en el título archivado. La notificación se realiza de manera simultánea en ambos domicilios, entendiéndose válidamente realizada en cualquiera de ellos.

\section{Artículo 58. Verificación de la autenticidad de la solicitud de cancelación}

Cuando el juez o el funcionario público no de respuesta en el plazo previsto en el párrafo 57.3 del presente Reglamento, sin perjuicio de la responsabilidad por dicha omisión, el servidor de la SUNARP se apersona a su despacho con la finalidad de verificar la autenticidad de la solicitud de cancelación presentada.

\section{Artículo 59. Contradicción de la solicitud de cancelación}

59.1. El titular registral tiene un plazo máximo de cinco (5) días hábiles para formular su contradicción, la cual solo puede fundamentarse en algún supuesto de improcedencia o error en la declaración de la autoridad o funcionario legitimado. En este último caso, el Jefe Zonal pone dicha circunstancia en conocimiento de la autoridad o funcionario legitimado para que en un plazo máximo de veinte (20) días hábiles confirme su pedido de cancelación.

59.2. Si la autoridad o funcionario legitimado confirma su solicitud de cancelación, el procedimiento continúa y el Jefe Zonal dispone la cancelación del asiento irregular. Si la solicitud de cancelación no se confirma en el plazo establecido, el procedimiento concluye y se deriva el título al registrador a fin de que proceda con la tacha.

\section{Artículo 60. Plazos para la emisión de la resolución jefatural}


60.1. Si la autoridad o funcionario legitimado confirma su solicitud de cancelación o el titular registral no formula contradicción, el Jefe Zonal tiene un plazo máximo de diez (10) días hábiles para disponer la cancelación del asiento registral irregular.

60.2. Si la autoridad o funcionario legitimado no confirma su solicitud de cancelación o resulta estimatoria la contradicción sustentada en alguna causal de improcedencia, el Jefe Zonal tiene un plazo máximo de cinco (5) días hábiles para emitir la resolución jefatural que desestima la solicitud de cancelación.

60.3. El Jefe Zonal puede tomar en cuenta las comunicaciones remitidas por la autoridad o funcionario legitimado fuera del plazo mencionado previamente, siempre y cuando no se haya emitido la respectiva resolución jefatural.

\section{Artículo 61. Notificación de la resolución jefatural}

La resolución jefatural que dispone la cancelación de un asiento registral irregular o que la deniega por inadmisibilidad o improcedencia es remitida al registrador. El Jefe Zonal debe notificar a la autoridad o funcionario legitimado y al titular registral vigente.

\section{Artículo 62. Plazo para formular la cancelación de un asiento registral irregular}

62.1. Cuando se genere una inscripción posterior al asiento registral irregular que se encuentre referida a un acto de disposición o gravamen, la autoridad o funcionario legitimado solicita la cancelación del asiento registral irregular ante el Jefe Zonal de la oficina registral en el plazo de un (1) año. El plazo se computa a partir de la fecha del asiento de presentación del título que dio mérito al asiento registral irregular que se pretende cancelar.

62.2. En aquellos casos en los que no se haya extendido un asiento que contenga un acto de disposición o gravamen posterior al asiento registral irregular, el plazo para solicitar la cancelación es de diez (10) años.

\section{SUB CAPÍTULO III}

\section{EJECUCIÓN DE LA CANCELACIÓN EN SEDE ADMINISTRATIVA}

\section{Artículo 63. Ejecución de la cancelación}

63.1 El Jefe Zonal dispone que la cancelación de un asiento registral irregular vigente se extienda en el mismo rubro en el que se encuentra el asiento registral irregular.

63.2 Cuando se cancele un asiento registral irregular no vigente, el Jefe Zonal dispone la extensión en el rubro de cancelaciones de la partida registral donde obra el asiento registral irregular. 
63.3 En el caso de aquellos registros cuya organización de la partida registral no contemple un rubro de cancelaciones, debe indicarse expresamente en la partida registral que el asiento de cancelación tiene tal condición.

63.4 La cancelación de un asiento registral irregular extendido en el Registro de Propiedad Inmueble o en el Registro de Bienes Muebles no constituye una carga o gravamen.

\section{Artículo 64. Contenido del asiento de cancelación}

64.1. El asiento de cancelación debe contener lo siguiente:

1. La indicación del asiento que se cancela.

2. El acto o derecho que queda sin efecto por la cancelación.

3. El supuesto de la cancelación conforme a la Ley No 30313.

4. La autoridad o funcionario legitimado que solicitó la cancelación.

5. El número de la resolución jefatural y el nombre del Jefe Zonal que lo expidió.

6. La indicación a la que se refiere el párrafo 63.3 del presente Reglamento, cuando corresponda.

7. Los demás requisitos señalados en el TUO del Reglamento General de los Registros Públicos.

64.2 Cuando se cancele un asiento registral irregular no vigente, al extender el asiento de cancelación el registrador debe dejar constancia de que no se perjudica al titular registral que tenga la calidad de tercero, conforme al artículo 2014 del Código Civil.

\section{Artículo 65. Decisión irrecurrible en sede administrativa}

La resolución jefatural que dispone la cancelación de un asiento registral irregular o que la desestima por inadmisibilidad o improcedencia, es irrecurrible en sede administrativa.

\section{Artículo 66. Impugnación ante el Poder Judicial}

66.1. El titular registral perjudicado por la inscripción del asiento de cancelación dispuesta por el Jefe Zonal puede solicitar su declaración judicial de invalidez.

66.2. De la misma manera, el afectado por la extensión de un asiento registral irregular que no hubiera sido cancelado en sede administrativa, tiene expedito su derecho para solicitar su declaración de invalidez ante el Poder Judicial.

\section{Artículo 67. Correlación del asiento de cancelación en sede administrativa}

Cuando en el Registro de Mandatos y Poderes o en el Registro de Personas Jurídicas, el registrador extienda un asiento de cancelación referido a un título en donde constan las 
facultades para transferir o gravar algún bien, así como la indicación de su partida registral, también debe extender el asiento de correlación en la partida registral del Registro de Bienes en forma simultánea.

\section{SUBCAPÍTULO IV}

\section{ANOTACIÓN PREVENTIVA NOTARIAL}

\section{Artículo 68. Plazo para solicitar la anotación preventiva notarial}

68.1. La anotación preventiva notarial se extiende aun cuando el titular registral sea un tercero, siempre que se solicite dentro del plazo de un (1) año contado desde la fecha del asiento de presentación del título que dio mérito al asiento registral irregular.

68.2. En aquellos casos en los que no se haya generado ningún asiento que contenga un acto de disposición o gravamen posterior al asiento registral irregular, el plazo para extender la anotación preventiva es de diez (10) años contados desde la misma fecha a que se refiere el párrafo precitado.

\section{Artículo 69. Levantamiento de anotación preventiva}

69.1. Una vez vencido el plazo de la anotación preventiva, esta caduca de pleno derecho. El asiento de cancelación de la anotación preventiva puede extenderse de oficio o a petición de parte.

69.2. Si no hubiera transcurrido el plazo de un (1) año contado desde la fecha de presentación del respectivo título en mérito al cual se realizó la anotación, esta solo puede ser levantada a solicitud del notario a cuyo ruego se extendió.

\section{Artículo 70. Improcedencia de la renovación de anotación preventiva}

La renovación de la anotación preventiva es improcedente. En aquellos casos en los que el notario la solicite cuando ha transcurrido el plazo de caducidad, debe extenderse como una nueva anotación.

\section{DISPOSICIONES COMPLEMENTARIAS FINALES}

\section{Primera. Acta de identificación y solicitud de oposición}

La SUNARP aprueba los formatos del acta de identificación y del formulario de solicitud de oposición en el plazo de treinta (30) días hábiles contados desde el día siguiente de la publicación del presente Reglamento.

\section{Segunda. Directiva de SUNARP sobre el uso del servicio de Alerta Registral}

La SUNARP aprueba la directiva que regula el procedimiento para la suscripción de oficio y baja del servicio de Alerta Registral en un plazo de sesenta (60) días hábiles contados desde el día siguiente de la publicación del presente Reglamento. 
La SUNARP se encuentra facultada para ampliar los actos y registros para la suscripción de oficio del servicio de Alerta Registral.

\section{Tercera. Facultad de la SUNARP}

La SUNARP aprueba las disposiciones o lineamientos necesarios para el cumplimiento del presente Reglamento.

\section{Cuarta. Aplicación supletoria de la Ley Nº 27444}

Para los supuestos no previstos en el presente Reglamento se aplica de manera supletoria, las disposiciones previstas en la Ley $N^{o}$ 27444, Ley del Procedimiento Administrativo General.

\section{Quinta. Coordinación entre el Ministerio de Relaciones Exteriores y la SUNARP}

El Ministerio de Relaciones Exteriores puede acreditar ante la SUNARP a uno o más funcionarios autorizados para que, en representación del cónsul, formulen oposición o cancelación, así como cualquier actuación necesaria dentro de los procedimientos regulados en el presente Reglamento.

Los presentantes del Ministerio de Relaciones Exteriores deben ser debidamente acreditados ante la SUNARP.

La SUNARP y el Ministerio de Relaciones Exteriores deben coordinar la forma de acreditación de los funcionarios autorizados y presentantes ante el Registro.

Sexta. Anotación preventiva en el Registro de Personas Jurídicas por falsificación en la certificación notarial de apertura de libro

En el caso de inscripción sustentada con la copia certificada de un acta asentada en el libro cuya certificación notarial es falsa, el notario que supuestamente habría certificado la apertura del libro debe solicitar la anotación preventiva en el Registro de Personas Jurídicas en un plazo no mayor de tres (3) días hábiles de conocer este hecho, bajo su responsabilidad.

La anotación preventiva tiene una vigencia de un (1) año contado a partir de la fecha del asiento de presentación.

Sétima. Anotación preventiva en el Registro de Personas Jurídicas por suplantación para la certificación notarial de apertura de libro

En el caso de inscripción sustentada con la copia certificada de un acta asentada en el libro cuya apertura se realizó suplantando la identidad del apoderado o representante legal de la persona jurídica, el notario que certificó la apertura del libro debe solicitar la 
anotación preventiva en el Registro de Personas Jurídicas en un plazo no mayor de tres (3) días hábiles de conocer este hecho, bajo su responsabilidad.

La anotación preventiva tiene una vigencia de un año contado a partir de la fecha del asiento de presentación.

\section{DISPOSICIONES COMPLEMENTARIAS TRANSITORIAS}

Primera. Aplicación de la norma en el tiempo para nulidad de escritura pública

Se encuentra excluida de las causales de nulidad la escritura pública otorgada antes de la vigencia del artículo 4 del Decreto Legislativo $\mathrm{N}^{\circ} 1049$, modificado por la Ley $\mathrm{N}^{\circ}$ 30313 y el Decreto Legislativo $\mathrm{N}^{\mathrm{0}}$ 1232, y cuyo proceso de conclusión de firmas se efectuó dentro de los alcances de las restricciones previstas en dichas normas.

Segunda. Actos que no se encuentran dentro de los supuestos para nulidad de escritura pública

Las escrituras públicas de otorgamiento de poder se encuentran excluidas de los supuestos de nulidad de escrituras públicas previstas en el artículo 4 del Decreto Legislativo $N^{\circ} 1049$, modificado por la Ley No 30313 y el Decreto Legislativo No $^{\circ} 1232$. 


\title{
Anexo 3: Resolución del Superintendente Nacional de los Registros Públicos N 265-2016-SUNARP-SN
}

\author{
RESOLUCION DEL SUPERINTENDENTE NACIONAL DE LOS REGISTROS
} PUBLICOS N 265-2016-SUNARP-SN. Publicado en el diario Oficial El Peruano el 28 de Setiembre del 2016. Aprueban formulario de solicitud de oposición de título en trámite

Lima, 27 de setiembre de 2016

VISTO, el Informe N $^{\circ}$ 221-2016-SUNARP/DTR, del 27 de setiembre de 2016, emitido por la Dirección Técnica Registral, y;

\section{CONSIDERANDO:}

Que, la Superintendencia Nacional de los Registros Públicos - Sunarp, es un Organismo Técnico Especializado del Sector Justicia, que tiene por objeto dictar las políticas técnico administrativas de los Registros Públicos, estando encargada de planificar, organizar, normar, dirigir, coordinar y supervisar la inscripción y publicidad de los actos y contratos en los Registros Públicos que integran el Sistema Nacional, en el marco de un proceso de simplificación, integración y modernización de los Registros;

Que, mediante la Ley N 30313 se regula la oposición al procedimiento de inscripción registral en trámite y la cancelación del asiento registral por suplantación de identidad o falsificación de documentación, entre otros temas;

Que, mediante Decreto Supremo No 010-2016-JUS, se aprueba el Reglamento de la Ley N ${ }^{o}$ 30313, Ley de Oposición al Procedimiento de Inscripción Registral en Trámite y Cancelación del Asiento Registral por Suplantación de Identidad o Falsificación de Documentación y Modificatoria de los Artículos 2013 y 2014 del Código Civil y de los Artículos 4 y 55 y la Quinta y Sexta Disposiciones Complementarias Transitorias y Finales del Decreto Legislativo 1049;

Que, en la primera disposición complementaria final del mencionado reglamento se encarga a la Superintendencia Nacional de los Registros Públicos la aprobación del acta de identificación y el formulario de solicitud de oposición; 
Que, el acta de identificación es el formato mediante el cual, si por razones de fuerza mayor o caso fortuito no se puede utilizar el lector biométrico del Reniec, acredita la identificación de quién se apersona ante la Oficina Registral para solicitar la oposición al procedimiento de inscripción registral en trámite o la cancelación de un asiento de inscripción irregular;

Que, en el caso de la cancelación del asiento registral irregular, la presentación se realiza mediante un título en la oficina de diario y, para ello, está previsto el acta de identificación denominado "Autorización para ingreso de Título", aprobado por Resolución No 181-2015-SUNARP-SN;

Que, en el caso de la oposición de un título en trámite, la presentación se realiza en mesa de partes, el servidor también podrá utilizar el acta de identificación denominado “Autorización para ingreso de Título”, aprobado por Resolución No 181-2015-SUNARP$\mathrm{SN}$

Contando con el visado de la Dirección Técnica Registral, de la SUNARP;

Estando a lo acordado y, de conformidad con la facultad conferida por el literal x) del artículo 9 del Reglamento de Organización y Funciones de la SUNARP, aprobado por Decreto Supremo No 012-2013-JUS;

\section{SE RESUELVE:}

Artículo Primero.- Aprobar el formulario solicitud de oposición de título en trámite.

Articulo Segundo.- Precisar que el acta de identificación señalado en el Reglamento de la Ley $N^{\circ}$ 30313, aprobado por Decreto Supremo $N^{\circ}$ 010-2016-JUS, será el denominado "Autorización para ingreso de Título", aprobado por Resolución $\mathrm{N}^{\mathrm{o}} 181$ 2015-SUNARP-SN.

Artículo Tercero.- Disponer que el formulario de solicitud de oposición de título en trámite pueda obtenerse de la página web de la Sunarp, así como de las Oficinas Registrales.

Regístrese, comuníquese y publíquese.

$$
\text { MARIO SOLARI ZERPA }
$$

Superintendente Nacional de los Registros Públicos 